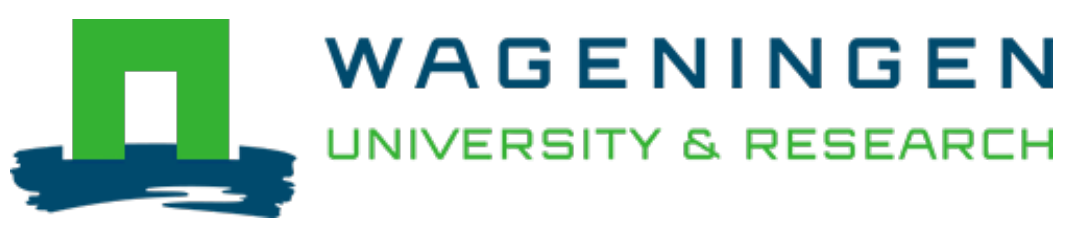

\title{
Effects of input vouchers and rainfall insurance on agricultural production and household welfare: Experimental evidence from northern Ethiopia
}

\author{
World Development \\ Wong, H.L.; Wei, X.; Kahsay, H.B.; Gebreegziabher, Z.; Gardebroek, C. et al \\ https://doi.org/10.1016/j.worlddev.2020.105074
}

This publication is made publicly available in the institutional repository of Wageningen University and Research, under the terms of article $25 \mathrm{fa}$ of the Dutch Copyright Act, also known as the Amendment Taverne. This has been done with explicit consent by the author.

Article 25 fa states that the author of a short scientific work funded either wholly or partially by Dutch public funds is entitled to make that work publicly available for no consideration following a reasonable period of time after the work was first published, provided that clear reference is made to the source of the first publication of the work.

This publication is distributed under The Association of Universities in the Netherlands (VSNU) 'Article $25 \mathrm{fa}$ implementation' project. In this project research outputs of researchers employed by Dutch Universities that comply with the legal requirements of Article $25 \mathrm{fa}$ of the Dutch Copyright Act are distributed online and free of cost or other barriers in institutional repositories. Research outputs are distributed six months after their first online publication in the original published version and with proper attribution to the source of the original publication.

You are permitted to download and use the publication for personal purposes. All rights remain with the author(s) and / or copyright owner(s) of this work. Any use of the publication or parts of it other than authorised under article $25 \mathrm{fa}$ of the Dutch Copyright act is prohibited. Wageningen University \& Research and the author(s) of this publication shall not be held responsible or liable for any damages resulting from your (re)use of this publication.

For questions regarding the public availability of this publication please contact openscience.library@wur.nl 


\title{
Effects of input vouchers and rainfall insurance on agricultural production and household welfare: Experimental evidence from northern Ethiopia
}

\author{
Ho Lun Wong ${ }^{\mathrm{a}, *}$, Xiangdong Wei ${ }^{\mathrm{b}}$, Haftom Bayray Kahsay ${ }^{\mathrm{c}}$, Zenebe Gebreegziabher ${ }^{\mathrm{d}}$, \\ Cornelis Gardebroek ${ }^{\mathrm{e}}$, Daniel E. Osgood ${ }^{\mathrm{f}}$, Rahel Diro ${ }^{\mathrm{g}}$
}

${ }^{a}$ Department of Business and Economics, Wheaton College, IL, USA

${ }^{\mathrm{b}}$ Department of Economics, Lingnan University, Hong Kong Special Administrative Region

${ }^{\mathrm{c}}$ Department of Economics, Mekelle University, Ethiopia

${ }^{\mathrm{d}}$ Department of Economics, Mekelle University, Ethiopia

${ }^{\mathrm{e}}$ Agricultural Economics and Rural Policy Group, Wageningen University, the Netherlands

${ }_{\mathrm{f}}^{\mathrm{f}}$ International Research Institute for Climate and Society, Columbia University, NY, USA

${ }^{\mathrm{g}}$ International Research Institute for Climate and Society, Columbia University, NY, USA

\section{A R T I C L E I N F O}

\section{Article history:}

Accepted 2 July 2020

\section{JEL classification:}

C93

D24

G22

012

013

016

\section{Keywords:}

Agricultural input vouchers

Rainfall index insurance

Agricultural production

Randomized controlled trial

Productive Safety Net Programme

Rural Ethiopia

\begin{abstract}
A B S T R A C T
We report on a randomized field experiment designed to relax credit and risk constraints for agricultural activities. We conducted a study in a drought-prone region in northern Ethiopia among poor smallholders who depended on rainfed agriculture and were members of the Productive Safety Net Programme (PSNP). Data were collected from over 1100 farmers in 32 rural villages over two years. We find that unconditional voucher transfers designated for the purchase of agricultural inputs significantly increased usage of seeds and fertilizers (a flypaper effect), raised the amount of farmland used (a complementary effect), and induced substitution of own effort by hiring casual labor (a local spillover effect). Subsidized rainfall insurance with reduced input vouchers produced weak average effects but greatly increased investments for farmers who were relatively more patient. We do not find heterogeneous effects by farmers' risk attitudes, however, suggesting that the effects of insurance adoption were mainly determined by how farmers in the safety net made tradeoffs inter-temporally. Insurance demand dropped quickly with the reduction in subsidy and did not correlate with time or risk preference. Therefore, to improve cost-effectiveness, insurance programs should include procedures that help identify forward-looking farmers and encourage their adoption. While our results show that initial subsidies increase future insurance demand, the effect was small and thus initial subsidies would not be a cost-effective mechanism for financially sustainable insurance. Other complementary strategies on the design, promotion, and bundling techniques of insurance would be needed.
\end{abstract}

(c) 2020 Elsevier Ltd. All rights reserved.

\section{Introduction}

Poor farmers in developing countries face credit and risk constraints that limit production and affect livelihoods. In response, many governments have established safety nets and input subsidy programs to help poor farmers improve farming intensity and

\footnotetext{
* Corresponding author.

E-mail addresses: alex.wong@wheaton.edu (H.L. Wong), xdwei@ln.edu.hk (X. Wei), koos.gardebroek@wur.nl (C. Gardebroek), deo@iri.columbia.edu (D.E. Osgood), rld@iri.columbia.edu (R. Diro).
}

enhance food and income security. ${ }^{1}$ In recent years, innovations in rainfall insurance also have increased the availability of agricultural

\footnotetext{
${ }^{1}$ Effects of different types of credit-relaxing programs differ. Cash transfer and social protection programs, such as the Malawi Social Cash Transfer Scheme and the Ethiopian Productive Safety Net Programme, have been found to raise food consumption and household expenditure, and their effects on promoting agriculture vary (Maluccio, 2010; Miller, Tsoka, \& Reichert, 2011; Hoddinott et al., 2012). Conditional cash transfer programs, such as Progresa (later renamed Oportunidades) in Mexico and Bolsa Escola in Brazil, aim to further promote long-term investment in children's schooling or health (Schultz, 2004; de Janvry et al., 2006; Todd, Winters, \& Hertz, 2010; de Brauw \& Hoddinott, 2011; Filmer \& Schady, 2011). Input subsidy programs, such as the Agricultural Input Subsidy Program in Malawi and the Input Trade Fairs in Mozambique, aim to promote agricultural activities by providing farmers with subsidized seeds and fertilizers (Morris et al., 2007; Jayne, Mason, Burke, \& Ariga, 2018).
} 
risk protection (Barnett \& Mahul, 2007; Chantarat, Barrett, Mude, \& Turvey, 2007; Greatrex et al., 2015; Hellmuth, Osgood, Hess, Moorhead, \& Bhojwani, 2009). Through supporting smallholders to formally manage weather risks ex ante, rainfall insurance has been advocated as a supplementary tool to encourage the voluntary purchase or financing of inputs and stimulate technology adoption (Cai, 2016; Cole, Bastian, Vyas, Wendel, \& Stein, 2012; Dercon, 2004; Karlan, Osei, Osei-Akoto, \& Udry, 2014). ${ }^{2}$

Although scaling insurance to support ex ante risk protection is conceptually advantageous to simply providing ad hoc postdisaster relief (Alderman \& Haque, 2007; Barnett, Barrett, \& Skees, 2008; Devereux, 2016), the uptake of commercial rainfall insurance in developing countries is generally low (Cole et al., 2013; de Janvry, Dequiedt, \& Sadoulet, 2014; Giné, Townsend, \& Vickery, 2008; Platteau, De Bock, \& Gelade, 2017). ${ }^{3}$ Therefore, some experts suggest that governments and donors should include rainfall insurance as part of the government protection agenda and offer farmers insurance subsidy at least initially (Churchill, 2006; Hellmuth et al., 2009; High Level Panel of Experts2012; IFAD and WFP, 2010; Mahul \& Stutley, 2010; Devereux, 2016; Results, 2016). The rationale is that as farmers gain knowledge and experience about the insurance, demand and adoption may increase and subsidies may be phased out. Nevertheless, there are concerns that the use of initial subsidies may not effectively promote future adoption, particularly if farmers do not receive payouts. Overall, it is also not clear if this promotion strategy may help achieve financial sustainability of insurance programs at scale.

Given a certain program budget, there also lacks understanding of whether it is more effective to promote agriculture through conventional interventions, such as subsidizing inputs directly, or bundling these conventional interventions with subsidized insurance. Karlan et al. (2014) show that rainfall insurance outperforms unconditional cash grants in stimulating farm investments and promoting technological adoption for maize production in Ghana. Jensen, Barrett, and Mude (2017) also find that a livestock insurance program produces more impact per marginal cost than a cash transfer program. While there are virtues in these comparisons, it is noteworthy that rainfall insurance is designed to alleviate agricultural risk constraints whereas cash transfers often support food intake and daily consumption. Therefore, agricultural subsidy programs, which have been reemerging in many developing countries,

\footnotetext{
${ }^{2}$ Evidence for the effectiveness of rainfall insurance in promoting agriculture is overall mixed. Cole et al. (2017) find that providing insurance before the monsoon season encourages Indian farmers to invest in higher-return, rainfall-sensitive cash crops. Cai (2016) shows that compulsory insurance adoption can cost-effectively increase agricultural borrowing and production among Chinese tobacco farmers. Madejewicz and Tsegay (2013) and Madejewicz et al. (2017) have also shown that insurance integrated into a suite of interventions have produced development impacts in the R4 project in our study area, which include increased input use, savings, and asset (livestock). However, Giné and Yang (2009) show that making loans to Malawian farmers conditional on insurance adoption reduces the loaned amounts and the purchase of improved seeds. Ahmed et al. (2017) find that insurance participation does not increase inputs or farm output in Ethiopia, and Tobacman et al. (2017) report similar results for Indian farmers.

${ }^{3}$ Many studies have analyzed the determinants of insurance demand. For example, Giné et al. (2008) show that insurance adoption among Indian smallholders decreases with credit constraints, increases with household wealth, and decreases with basis risk. In several field experiments in rural India, Cole, Giné, and Vickery (2013) identify barriers to insurance adoption, such as lack of trust, low financial literacy, liquidity constraints, and limited product salience. Duru (2016) uses matching methods and finds that enrollment in government protection programs reduces insurance demand among Ethiopian farmers. Other studies propose different marketing techniques, such as education and training (Gaurav, Cole, \& Tobacman, 2011; Norton et al., 2014), providing insurance information to peers (Cai, De Janvry, \& Sadoulet, 2015), and selling insurance to groups (de Janvry, Finan, Sadoulet, \& Vakis, 2014), for promoting insurance adoption. Nevertheless, these marketing techniques are unlikely to be sufficient to scale up insurance in developing countries, which adds to the case for subsidizing insurance, at least at an initial stage.
}

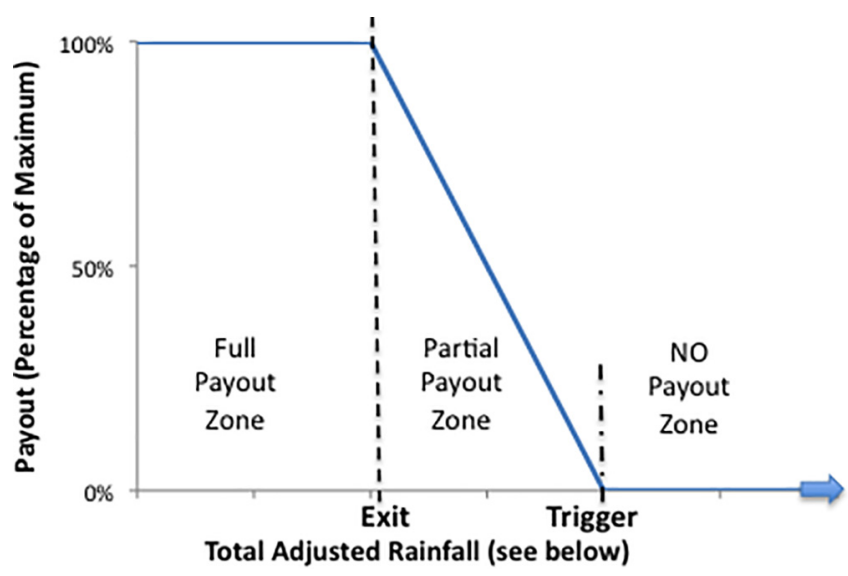

Fig. 1. Main design features of weather index agricultural insurance.

may offer a more comparison with rainfall insurance on evaluating program effects on promoting agriculture.

Another important consideration is whether farmers who enroll in government protection programs may benefit from additional insurance protection against rainfall risks. These farmers typically expect to receive government aid following major weather shocks and, as some of potential losses are implicitly insured, may lack incentives to get the most from the rainfall insurance. Studies also have shown that insurance demand does not necessarily increase with risk aversion (Carter, Cheng, \& Sarris, 2016; Clarke, 2016) and instead may depend more on how farmers make intertemporal decisions (Hellmuth et al., 2009). Therefore, it is important to investigate whether the risk and time preferences of farmers who enrolled in government protection programs mediate the demand for and effects of rainfall insurance.

In this study we aim to answer three sets of questions about initiatives that governments and donor agencies can adopt to promote the agricultural production of farmers enrolled in government protection programs. First, should governments and donors adopt a traditional approach and subsidize inputs alone (i.e., alleviating cash or credit constraints)? Or would farmers better intensify farming activities in the short term with a program that also provides a subsidized rainfall insurance (i.e., addressing agricultural risk constraints ex ante) while lowers the amount of input subsidy? Second, how do the effects of these programs differ among farmers who have different characteristics and farming scales? Specifically, given the risk and time factors involved in production, does the effectiveness of the programs correlate with farmers' attitudes toward risk and time? Third, how sensitive are farmers enrolled in government protection programs to the price of insurance? What are the boarder determinants of insurance participation? Also, do farmers who previously have experienced subsidized insurance exhibit a higher demand in the future?

To answer these questions, we conducted a two-year randomized controlled trial (RCT) in northern Ethiopia. Ethiopia is an ideal site for conducting our research because the government has established the Productive Safety Net Programme (PSNP) and has provided public works payments and unconditional transfers to over 8 million farmers in the past decade (World Bank, 2013, 2017). In addition, several rainfall insurance programs have been in place to complement PSNP initiatives and attempt to further promote agricultural activities. These programs have common donors who must work with the government to decide how to balance resources between different program instruments.

Our RCT was conducted in the drought-prone parts of the Tigray region in northern Ethiopia, with over 1100 farmers randomly selected from 32 rural villages. In the first year, we randomly 
assigned the farmers to one of the two intervention groups or an untreated control group. Farmers in the first intervention group received a voucher that subsidized purchase of agricultural inputs. The voucher provided a moderate level of support and had a value of about $25 \%$ of farmers' average total agricultural costs at baseline. In the second intervention group, we added a free rainfall insurance grant, which was calibrated to compensate the farmers' average total agricultural costs at baseline in the worst droughts, and the value of the input vouchers was reduced to keep the total intervention costs similar. These two intervention arms thus allowed us to evaluate which arrangement-input vouchers alone or free rainfall insurance with reduced vouchers-can more effectively promote agriculture.

In the second year, we further analyzed the sensitivity to price and other determinants of insurance demand. We provided all previously treated farmers with a standard input voucher and a chance to purchase rainfall insurance at randomized subsidy levels. Farmers would need to pay for parts of the premium if they decided to participate. Therefore, we could be able to test the effectiveness of the insurance promotion strategy which involves large initial subsidies. The control group remained untreated.

We evaluate the one- and two-year effects of our two intervention programs using difference-in-differences and instrumental variable (IV) estimation approaches respectively. Importantly, over the two-year study period, there were no notable droughts and only minimal payouts were provided to a few insured farmers. Our study is thus distinctive as the lack of weather shocks and payouts allows us to focus on examining the ex ante insurance effect through alleviating agricultural risk constraints. Despite the importance, our study does not examine the ex post insurance effect through receiving payouts and smoothing income.

We first find that the provision of input subsidies significantly increased agricultural investments. The provision of input vouchers alone increased the purchase and use of farming inputs (mainly seeds and fertilizers) by about $40-50 \%$ of the voucher value, suggesting the presence of an important flypaper effect of the vouchers on farming decisions (Fafchamps, McKenzie, Quinn, \& Woodruff, 2014). These results contrast with those of other studies that have found more general cash transfers to be ineffective in promoting agriculture (e.g., Karlan et al., 2014). The effect of the vouchers on total agricultural costs was also found to be larger for farmers who had a smaller farming scale.

On average, farmers receiving input vouchers also increased their use of farmland by doing less sharecropping as landowners, conducting more sharecropping as laborers, and leaving less fallow. These results suggest that the provision of inputs produced a complementary effect on farming decisions. Interestingly, these farmers were found to reduce their own farming effort on land preparation and sowing and hire more casual labor from the community. The average wage bill was about $20 \%$ of the voucher value, representing a spillover following the relaxation of cash constraints. Despite these observed changes, we do not find statistical evidence that the input voucher intervention increased the value of farm output. However, we find some evidence that subsidizing inputs increased ownership of agricultural productive assets and reduced the amount of private transfers received.

Subsidized insurance bundled with reduced input vouchers (or the insurance-voucher bundle) apparently produced weak effects in general. While the program also increased the purchase of seeds in the first year, there was no statistical evidence of increase in the total purchase or the total usage cost of agricultural inputs. The bundle increased the amount of farmland cultivated and reduced own farming effort on sowing, however, the farmers did not hire more labor from the community. We observed no further program effects on major household financial outcomes other than a decline in private transfers received.
Importantly, we do not find heterogeneous effects of the two intervention programs by farmers' risk aversion. In contrast, farmers who were more patient and had a weaker discounting on time were found to make more farm investments upon receiving the insurance-voucher bundle. Our results thus suggest that rainfall insurance should best target forward-thinking farmers to undertake agricultural investments for improving future livelihoods (Duflo, Kremer, \& Robinson, 2011).

Our analysis of insurance demand further demonstrates the challenges and opportunities of scaling insurance. We find that granting free insurance in the first year raised demand in the second year despite the lack of major droughts and payouts. Nevertheless, the increase from the insurance experience was small and was weaker than the effects of raising current subsidy rates by 10 percentage points. Therefore, tapering down subsidies from initially generous levels is unlikely to be a cost-effective way to nurture demand; other strategies, such as exposing farmers to insurance games or easing liquidity constraints, should be adopted instead, as motivated by much of the literature, and as strategies explored by insurance projects such as the nearby R4 effort (Cole, Stein, \& Tobacman, 2014; Giné et al., 2008; Norton et al., 2014; Vasilaky, Diro, Norton, McCarnery, \& Osgood, 2018).

We also find that insurance demand dropped quickly with the reduction in current subsidy levels. When farmers received a generous subsidy in the current year (e.g., 80\%), the insurance participation rate was high ( $80 \%$ following the example). However, after the subsidy rate went to $40 \%$, only about $25 \%$ of the farmers obtained the insurance. Therefore, untargeted offering of commercial or lightly subsidized rainfall insurance in rural communities unlikely can attract a high or sustainable level of uptake. We further analyze other determinants of insurance demand and do not find that more patient farmers exhibited stronger participation. Participation also was not statistically associated with their levels of risk aversion. We do find, however, that insurance demand was weaker among farmers who were members of informal savings and credit associations. This suggests that promotion efforts can be more effective when they complement existing financial networks and do not compete with them.

The remainder of this study is as follows. Section 2 describes the study region and relevant policy background in Ethiopia. Section 3 details our fieldwork. Section 4 presents our statistical approaches and empirical results. Section 5 examines potential effect heterogeneities. Section 6 discusses and concludes.

\section{Research region and policy background}

The Tigray region is in northern Ethiopia and is predominately rural. However, given its complex terrain, arid climate, and the effects of environmental degradation, only $15 \%$ of the land is cultivable. The average landholding of rural households is below one hectare, and most rural households are smallholders practicing rainfed agriculture and lack access to financial services and agricultural technologies. The rainy season starts in June and ends in September, and annual rainfall fluctuates between 400 and $800 \mathrm{~mm}$. Widespread droughts and famines, such as those in 1973 and 1984, caused hundreds of thousands to starve to death (Gao \& Mills, 2017). Overall, the region is extremely poor, with per head rural income at only about US $\$ 2$ per day these days.

In 2005, Ethiopia launched the Productive Safety Net Program (PSNP) with generous contributions from multiple donors (Sharp, Brown, \& Teshome, 2006). The PSNP aims to help the rural poor, who face chronic food insecurity, meet basic food needs, preserve productive assets, and become agriculturally productive (Andersson, Mekonnen, \& Stage, 2011; Berhane, Gilligan, Hoddinott, Kumar, \& Taffesse, 2014; Filipski et al., 2017; Gilligan, 
Hoddinott, \& Taffesse, 2009; Hoddinott, Berhane, O'Gilligan, Kumar, \& Taffesse, 2012). Farmers who are eligible for the program are invited to contribute labor to community work projects in return for cash and grain transfers. ${ }^{4}$ In Tigary, the PSNP currently covers 31 of the 35 districts (Weredas) and supports over 1 million beneficiary households in around 650 villages (Kebeles). ${ }^{5}$

In recent years, some donors have also worked with the Ethiopian government to implement risk management programs that aim to incentivize poor farmers to invest in agricultural activities. For example, the R4 Rural Resilience Initiative has been working in rural communities since 2008 to promote adoption of rainfall insurance among other risk management strategies (Madejewicz \& Tsegay, 2013; Madejewicz, Tsegay, \& Lee, 2017; WFP, 2017). With the potential synergy between improving liquidity and mitigating risks in stimulating agriculture, the Ethiopian government and donors are concerned with whether going through the PSNP infrastructure would be a cost-effective way of offering rainfall insurance to the rural poor (World Bank, 2013, 2017). There are questions, in particular, about the viability of allocating some of the donor resources to subsidize rainfall insurance and whether doing so could advance the goals of incentivizing behavioral change, achieving sustainable scales, and beneficially impacting poor farmers who might also require donor-funded support (Vasilaky et al., 2018).

\section{Fieldwork and interventions}

\subsection{Sampling strategy}

Our sampling strategy comprised four steps. First, we selected four rural, drought-prone districts from the region. In this step, we first excluded 11 districts, of the region's 35, where rainfall insurance was already available. We then used the districts' official disaster risk profiles to rank the drought-proneness of the remaining 24 districts and selected four that were ranked among the highest. ${ }^{7}$ Our

\footnotetext{
${ }^{4}$ The enrollment criteria of the PSNP include having residency in food insecure areas, a history of food shortage, and a low level of household assets. The program also aims to invest in community infrastructure, expand public services, and promote environmental transformation. Except for the elderly, the disabled, and pregnant women, PSNP beneficiaries receive food and cash transfers by contributing labor to community public works. Examples of public works include soil and water conservation, irrigation, community road building, and improvement projects for schools, health posts, and farmer training centers. Beneficiaries typically graduate from the program once their level of productive assets passes a regional threshold, at which point they are considered able to meet basic food needs and withstand a modest income shock.

${ }^{5}$ We believe that there is little variability in the level of PSNP payments that beneficiaries receive in our study region. According to our local experts, PSNP payments for local public work contributions has been the same across Tigray, three kilograms of cereal per person per day. Only in some cases when cereal was not available farmers would instead receive cash equivalent, 40 birr per person per day. Cereal prices vary little across Tigray and there is no other source of payment variabilities. Importantly, in both study years, we conducted within-village randomization of sample farmers across experimental arms. Therefore, possible variabilities in the PSNP across villages will unlikely affect our research.

${ }^{6}$ According to our local experts, contingency funds at five percent of the total PSNP payments are available at the Woreda level. These funds, however, are not intended to benefit general PSNP members nor implicitly provide them a form of insurance against shocks. Instead, the funds are used for meeting several specific goals, including providing support to newly displaced persons who are ineligible for the PSNP, making corrections in the PSNP coverage due to other reasons of exclusion, addressing malnutrition problems among children who are under five years old, and providing immediate support to new PSNP members.

7 The drought-proneness of the districts was determined by the percentage of rural households that reported that droughts, out of all other kinds of shocks and disasters, had affected them most in the last five years. The four selected districts were GantaAfeshum (Eastern Zone), Gulo Maheda (Eastern Zone), Enderta (Southern Zone), and Hintalo-Wajirat (Southern Zone). The levels of drought-proneness for these districts were $51 \%, 55 \%, 40 \%$, and $52 \%$, respectively, all higher than the average regional drought-proneness of $32 \%$.
}

second step involved randomly selecting 32 drought-prone villages. In this step, we also used administrative information to identify villages that ranked drought as their primary natural hazard. We made the sample by randomly selecting eight drought-prone villages in each of the four districts.

As villages often include several hamlet communities (Kushets) at distance, our third step was to randomly select hamlets within villages, obtaining three hamlets from each sample village for a set of 96 hamlet communities. The final step involved the selection of farmers. We used recent administrative listings of PSNP beneficiaries and randomly selected 12 agricultural households from each of the sample hamlets. In total, we aimed to obtain a sample of 1152 farmers. ${ }^{8}$

\subsection{Experimental interventions}

\subsubsection{Input voucher intervention in the first year}

In April 2016, before the rainy season had begun, farmers assigned to this group were invited to an informational session and received an unconditional, non-transferrable voucher of 400 birr (approximately US\$18) for the purchase of agricultural inputs. The value of the vouchers was about $25 \%$ of the total financial cost that the average farmer spent on inputs, according to our baseline data. In the following weeks, farmers could use the vouchers and additional cash to purchase seeds, fertilizers, herbicides, pesticides, or tools. In our study region, the government has been responsible for supplying, pricing, and marketing inputs in the rural area. ${ }^{9}$ Typically, farmers can get access to inputs by making purchases at the credit and saving cooperatives in the village and then collecting the inputs from the farmer cooperatives nearby. There have been little variations in the prices of inputs across villages. Supply of inputs has also been stable. Importantly, in both years of study we conduct within-village randomization of sample farmers to experimental arms. Therefore, farmers receiving different interventions would not systematically face different access to or prices of inputs.

\subsubsection{Input voucher and rainfall insurance intervention in the first year}

As farmers faced rainfall risks that might limit their agricultural investments ex ante, in the second intervention we provided farmers with an intervention package that aimed to relax both cash and agricultural risk constraints. We provided farmers with a grant of rainfall insurance, whose market premium value was 300 birr (or US\$14), and an input voucher worth 200 birr (or US\$9, half of that provided to the first group). The second intervention was thus

\footnotetext{
${ }^{8}$ We follow Bloom (1995) to calculate the minimum detectable effect (MDE) of our randomized experiment. For any two-group comparison in our first-year RCT, the number of hamlet communities being randomized $(J)$ is 64 , the number of farmers in each hamlet community $(n)$ is 12 , and the proportion of communities assigned to the treatment $(P)$ is 0.5 . We set the significance level of the test $(\alpha)$ to be 0.05 and the power level of the test $(k)$ to be 0.8 . Our outcome variables are measures of farming and financial decisions of the household. We assume a within-community correlation in outcomes $(\rho)$ of 0.20 and a standard deviation $(\sigma)$ of over-time change in outcomes of 0.50 . Our RCT design can thus detect a relatively small treatment effect of a 0.188 standard deviation in the outcomes.

${ }^{9}$ Although the government of Ethiopia has started liberalizing the agricultural input sector following the market reforms in the 1990s, the government has still been involving heavily in the input markets and is responsible for tasks such as estimating the demand of inputs and meeting the estimated demand (Spielman et al., 2011). The public sector accounts for more than 80 percent of the total sales of improved seeds and the seed market is together managed by the state-owned Ethiopian Seed Enterprise (ESE), government extension networks, and other public distribution channels. The involvement of the private sector remains limited. Similarly, the stateowned Agricultural Inputs Supply Enterprise (AISE) has been the primary supplier of chemical fertilizers in the country.
} 
designed to have a program cost comparable to the first. ${ }^{10}$ Overall, we aim to evaluate whether a program bundling rainfall insurance and input subsidy, with a budget split roughly between them, can perform as well as the pure input voucher grant in promoting agriculture.

The indices of the insurance were developed by the International Research Institute for Climate and Society at Columbia University modeled after the design methodology used by the R4 insurance project in surrounding regions. Based on information collected from village participatory exercises, the institute developed indices for two major drought periods using satellite estimates of historical rainfall. ${ }^{11}$ The indices were calibrated to produce major payouts in roughly six of the worst droughts in the past 30 years. ${ }^{12}$ After validating the indices with local village experts, the pricing and contracting was completed by Nyala Insurance Share Company, an Ethiopian company with experience in offering rainfall insurance in the region. The total sum insured was about 1800 birr per contract, roughly equal to the total agricultural costs an average farmer made in the baseline.

In April 2016, farmers allocated to this group were invited to the village center for an informational session on rainfall insurance (additional to the one on vouchers). During the training, our fieldwork team described the historical patterns of droughts in the region, discussed their impacts on agriculture, highlighted the main features of rainfall insurance, and explained its potential benefits and limitations. The team also conducted interactive exercises to help farmers gain knowledge of how rainfall shocks could affect production and how insurance could help them manage rainfall risks. ${ }^{13}$ In early May, insurance contracts were provided to farmers through village credit and saving cooperatives.

\subsubsection{Allocation of farmers in the first year}

We allocated farmers to our three experimental arms randomly by hamlet communities within villages. In each sample village, we allocated one sample hamlet to the input voucher group, another to the input and insurance group, and a third to the control group. Each arm thus included 32 groups of 12 farmers assigned from different hamlets in sample villages.

\footnotetext{
10 As the rainfall insurance was commercially priced, with a standard premium loading-25\% for covering basic operating costs and profits-and was less tangible and salient than the input vouchers, the face cost of the second intervention program was designed to be 100 birr more than that of the first intervention.

11 The first index covered cases of severely late onset of rainfall at the planting stage and significant dry spells for long cycle crops after sowing. The second covered cases of severely early end of rainfall at the flowering stage and significant dry spells late in the season. An early index, designed using rainfall estimates from the African Rainfall Climatology Version 2.0 (ARC2) satellite, and a late hybrid index, designed using estimates from the ARC2 and the Moderate Resolution Imaging Spectroradiometer (MODIS) Enhanced Vegetation Index (EVI) satellites, were developed for the two contract windows. ARC2 estimates rainfall by measuring cloud thickness and MODIS EVI estimates rainfall by measuring vegetation canopy greenness. These estimates also differ by their start dates, spatial resolution, and measurement frequencies. ARC2 estimates have been widely used in developing index insurance in the region, and we have therefore guarded against possible basis risk from the ARC2-based index. To do this, we developed a hybrid index for the late window, when vegetation measures were also reliable. As both the early and the late indices could capture the worst dry years in the history, and as the most critical parts of the season are the same for major crops produced in the region (barley, wheat, teff, maize, and sorghum), we only needed to develop one set of indices to cover all major crops in the region.

12 As shown in Fig. 1, the indices had a rainfall trigger in millimeters, and there would be no payment for any higher level of total rainfall (no payout zone). Tota rainfall below the trigger would result in a payout, and the payout would increase with the rainfall gap (partial payout zone). A maximum payout would be reached at and below an exit point (full payout zone) to capture the most severe droughts. To improve the robustness of the indices against extreme rainfall variations, a daily rainfall cap was applied to discount excess rainfall and better account for dry spells.

13 At the end of the training, the team conducted a short quiz with a number of questions to assess the farmers' understanding of rainfall insurance. Over $80 \%$ of the answers were correct (see Appendix Table 1).
}

3.2.4. Input voucher and rainfall insurance intervention in the second year

In the second year, we redesigned our interventions to examine the demand for rainfall insurance among PSNP farmers. We first conducted a choice experiment, using a sequence of six decisions to gauge farmers' willingness to pay. In each of the decisions, farmers could choose to obtain a standard input voucher worth 300 birr. Alternatively, they could further opt to obtain subsidized insurance by making partial premium payments (subsidy rates varying from $40 \%$ to $90 \%$ ). Like those provided in the first year, each insurance policy had a premium value of 300 birr.

To ensure that farmers made their decisions carefully, we invited them to first participate in two hypothetical rounds of the choice experiment. At the end of each of these practice rounds, we randomly selected one of the subsidy rates and informed the participants of the corresponding outcomes. The third round was a real one and the farmers had to make their final choices. We then randomly drew one of the subsidy rates and provided farmers with the intervention accordingly. This second-year intervention was provided to all the farmers who were formerly treated. These farmers were invited to attend training in the village center, take part in the choice experiment, and receive the intervention. Farmers in the first-year control group remained untreated.

\subsubsection{Insurance premium and payout over the two years}

In the first year, we provided rainfall insurance grants to 384 farmers. The total premium amount was about 115,000 birr and the total liability insured was around 650,000 birr. In the second year, 409 farmers chose to obtain our subsidized insurance. The total premium amount and the total liability insured were about 123,000 birr and 700,000 birr, respectively. The region reported no drought in the two years of study. In the first year, rainfall was generally above the historical average. The size of the insurance payout was thus small, with a total of just 5200 birr paid to 35 farmers in the three villages that showed a minor shortage. In the second year, rainfall estimates were only slightly below the historical average. The final payout amount was about 12,000 birr, paid to 22 farmers in six villages. These payouts were small relative to the total premium value paid and the total liability insured. Importantly, in both years, the satellite rainfall estimates were in line with feedback provided by our village experts. We therefore received few complaints from farmers.

\subsection{Data collection}

We conducted farmer surveys in the Decembers of 2015, 2016, and 2017. We collected detailed information about socioeconomic background, agricultural production, and household financial conditions, which allowed us to examine the effects of the two interventions and evaluate the demand for and determinants of insurance participation.

\subsubsection{Outcome variables: Agricultural production and household finance}

The immediate outcomes of our interventions are variables on agricultural production. These include data on the purchase and use of different agricultural inputs (e.g., seeds, chemical fertilizer, compost fertilizer, herbicides, and pesticides), which are used to compute total amounts for input spending and use. Information on farmland was also collected, such as the amount of farmland owned, rented to others (sharecropping on own land), rented from others (sharecropping on others' land), and left fallowed. In addition, we obtained data on the number of labor days the farmers spent on different farming stages-land preparation, sowing, cultivation, and harvesting-and calculated the total number of farm labor days. We also asked about total wages spent on casual labor 
hired for assisting farm work. Finally, to assess the outcomes of agricultural activities, we asked farmers to report their crop production, from which we computed the total value of farm output.

The other set of outcomes consists of different variables on household finance. We collected data on income earned from providing off-farm labor, income earned from small businesses and trades, and spending on health and education. We also asked for itemized information that allowed us to compute the total value of agricultural productive assets and that of livestock. Other household financial conditions were also recorded, such as the amount of cash savings and the sum of private transfers the household received from or offered to others.

\subsubsection{Control variables: Baseline household characteristics}

A rich set of household characteristics collected in the baseline provided control variables for the regression analysis. Basic characteristics included the gender of the household head, their age, years of education, the size of the household, and the amount of farmland owned. As networks in the village might help farmers manage risks (Bhattamishra \& Barrett, 2010), we asked farmers whether they had membership in Mahber (religious associations), Iddir (burial associations), or Equub (savings and credit associations). Economic attitudes, such as risk and time preferences, were elicited with two sets of simple hypothetical choice exercises. To control for differences in levels of basic numeracy, we posed three simple math questions and used the number of correct answers as a measure.

\section{Empirical analysis}

\subsection{Descriptive statistics}

Table 1 presents the baseline characteristics of the 1149 farmers that we could interview both in the baseline and the midline survey (that is, the sample we use for evaluating the one-year effects of our programs). ${ }^{14}$ Their characteristics across the experimental arms are well balanced. Nearly half of the household heads were female, and the average age of all households was $47 .{ }^{15}$ These farmers had little education, less than two years on average, and the average household size was slightly above five. Over $60 \%$ of the farmers attended Orthodox Christian groups, Mahber, and around 35\% belonged to informal burial societies, Iddir. Although savings and credit associations, Equub, existed in the villages, few of the farmers were members. Their poverty-given that they were PSNP beneficiaries-may explain their limited participation in community savings.

Their levels of agricultural activity and production were low in the baseline, owing to their poverty and partly also a widespread drought in the region during the 2015 season. The average of total input costs that season was around just 1800 birr (or US\$90). About 750 birr was spent on seeds and another 750 birr on chemical fertilizer. Most farmers did not use herbicides or pesticides, but

\footnotetext{
14 In our baseline survey we were able to conduct interviews with a total of 1,152 farmers. In our midline survey, only three farmers did not show up, so we could interview almost all of the sample farmers. In our endline survey, we successfully interviewed 1,099 of the 1,149 farmers. The attrition rate over two years was low, 4.4 percent. As shown in Appendix Table 2, the attrition is only statistically lower at some of the insurance subsidy rates in the second-year experiment. Households that had a female head were slightly more likely absent in the endline (results not reported for the sake of brevity). Nevertheless, given the low level of overall attrition, we believe that attrition is a minor problem in our study and would not affect our results.

${ }^{15}$ We observe a high percentage of female-headed households in our sample because we selected our households only from PSNP beneficiaries. Female-headed households are typically poorer and chronically less food secure and are much more likely to be PSNP members (Devereux, 2006; Jones, Tafere, \& Woldehanna, 2010; World Bank, 2013; Milazzo and van de Walle, 2017).
}

many produced compost fertilizers from green waste or animal manure, with an average imputed cost of nearly 300 birr.

The average landholdings of the farmers were also low, at about just 2 timad of farmland (or 0.5 ha). ${ }^{16}$ On average, these farmers also rented out more land (for sharecropping with others) than they rented in (sharecropping on others' land), at 0.5 versus 0.2 timad. They fallowed a small amount of land, below 0.1 timad. These numbers suggest that farmers may have faced major credit or risk constraints and could not fully utilize their land for their own farming. ${ }^{17}$

Farming effort and crop output reported in the baseline season are also low. The average farmer spent only about 45 labor days on land, and this included activities such as land preparation ( 7 days), sowing (5 days), cultivation (23 days), and harvesting (10 days). Farmers spent about 70 birr (with daily wages at about 30 birr) to hire casual farm labor locally, contributing around 2.5 days of work. Given their extreme poverty and the bad weather conditions, the average value of crop output that season from these activities was low, at around 2000 birr (or US\$90).

Data on household financial conditions further illustrate the poverty of our sample farmers. On average the farmers earned around just 600 birr (or US\$27) from providing off-farm labor and another 600 birr from small business and trade. Livestock was the main type of asset, and the average value was roughly 5500 birr (or US\$250). Despite being active, these farmers had lows levels of agricultural productive assets, at only about 500 birr (or US\$23), suggesting that they had barely any farm tools. They had little cash savings, at only about 400 birr (or US\$18), and received more in private transfers from others than the help they offered, 350 birr versus 90 birr.

\subsection{Willingness and demand for rainfall insurance participation}

First, we use final-round responses obtained from the secondyear choice experiment to examine farmers' willingness in insurance participation (see Fig. 2). Table 2 further shows the percentage of participation choices for different premium subsidy levels, and their variability illustrates that insurance demand was highly sensitive to price. When our sample farmers received a generous subsidy, only needing to make payments of $20 \%$ on the $300 \mathrm{birr}$ premium, the insurance participation rate was high, at nearly $80 \%$. However, the level of participation willingness dropped almost by half, to $42 \%$, when the subsidy rate was only reduced to $60 \%$. In other words, less than half of the farmers were willing to pay 120 birr for insurance, even they had just received from us a 300 -birr input voucher. When the subsidy rate fell to $40 \%$, which was still a good level of support, only one-quarter of the PSNP farmers were willing to obtain the insurance. We did not ask for farmers' participation willingness at lower levels of premium subsidies, but such scenarios would very likely find even fewer farmers willing to pay for insurance.

Table 2 also shows that a first-year insurance grant helped increase voluntary adoption in the second year, despite that only trivial payouts were made to few farmers. Studies suggest that experience with insurance payouts increases demand (Cole et al., 2014; Hill \& Viceisza, 2012), but we find that experiencing insurance alone might already help. The effects across subsidy rates

\footnotetext{
${ }^{16}$ Farmland in Ethiopia, having been collectively owned and cannot be freely traded, was last redistributed over 15 years ago. PSNP farmers thus represented the poorest households on the spectrum of unequal landholdings, which typically resulted from further private rearrangements through household expansion and creation following redistribution.

${ }^{17}$ In the study region, sharecropping arrangements were more common than fixedrent contracts owing to the high level of rainfall risk. The landlords were generally poorer than the tenants, who could afford more inputs, and landlords would typically share $25-50 \%$ of the agricultural production.
} 
Table 1

Baseline characteristics of sample PSNP farmers across first-year experimental arms $(\mathrm{N}=1149)$.

\begin{tabular}{|c|c|c|c|c|c|}
\hline & $\begin{array}{l}\text { Input Voucher } \\
\text { (1) }\end{array}$ & $\begin{array}{l}\text { Input and Insurance } \\
(2)\end{array}$ & $\begin{array}{l}\text { Control } \\
(3)\end{array}$ & $\begin{array}{l}\text { Input Voucher - Control } \\
(1)-(3)\end{array}$ & $\begin{array}{l}\text { Input and Insurance - Control } \\
(2)-(3)\end{array}$ \\
\hline \multicolumn{6}{|l|}{ Household characteristics } \\
\hline Head gender ( 1 = Female; $0=$ Male $)$ & 0.44 & 0.45 & 0.47 & $-0.036(0.036)$ & $-0.024(0.036)$ \\
\hline Head age (years) & 47.34 & 46.84 & 47.66 & $-0.314(0.962)$ & $-0.815(0.980)$ \\
\hline Head years of education & 1.80 & 2.05 & 1.88 & $-0.063(0.196)$ & $0.165(0.204)$ \\
\hline Household size & 5.50 & 5.16 & 5.29 & $0.233(0.154)$ & $-0.110(0.152)$ \\
\hline Size of farmland (timad) & 2.15 & 2.14 & 2.34 & $-0.188(0.129)$ & $-0.198(0.126)$ \\
\hline Mahber membership ( $1=$ Yes; $0=$ No) & 0.61 & 0.61 & 0.63 & $-0.024(0.035)$ & $-0.020(0.035)$ \\
\hline Iddir membership $(1=$ Yes; $0=$ No $)$ & 0.35 & 0.39 & 0.35 & $-0.007(0.035)$ & $0.033(0.035)$ \\
\hline Equub membership $(1=$ Yes; $0=$ No $)$ & 0.08 & 0.07 & 0.09 & $-0.006(0.020)$ & $-0.020(0.020)$ \\
\hline Risk preference measure ( 0 to 12 ) & 5.96 & 5.73 & 5.33 & $0.601 *(0.326)$ & $0.383(0.328)$ \\
\hline Time preference measure ( 0 to 8 ) & 2.38 & 2.27 & 2.13 & $0.240(0.204)$ & $0.138(0.202)$ \\
\hline Numeracy score (0 to 3 ) & 1.41 & 1.44 & 1.35 & $0.066(0.081)$ & $0.098(0.082)$ \\
\hline \multicolumn{6}{|l|}{ Agricultural production } \\
\hline Cost on seeds (birr) & 728.70 & 793.59 & 769.93 & $-40.056(58.686)$ & $25.152(60.612)$ \\
\hline Cost on chemical fertilizer (birr) & 753.51 & 771.22 & 785.48 & $-31.333(50.308)$ & $-13.842(47.056)$ \\
\hline Cost on compost fertilizer (birr) & 292.69 & 299.60 & 271.22 & $22.153(57.799)$ & $29.090(64.130)$ \\
\hline Cost on herbicide/pesticide (birr) & 18.01 & 12.98 & 17.06 & $0.553(4.886)$ & $-4.421(3.636)$ \\
\hline Total agricultural input cost (birr) & 1792.91 & 1877.39 & 1843.69 & $-48.682(119.131)$ & $35.979(119.801)$ \\
\hline Farmland sharing in (timad) & 0.18 & 0.17 & 0.24 & $-0.055(0.051)$ & $-0.070(0.049)$ \\
\hline Farmland sharing out (timad) & 0.47 & 0.44 & 0.56 & $-0.092(0.075)$ & $-0.120(0.073)$ \\
\hline Farmland fallow (timad) & 0.10 & 0.07 & 0.04 & $0.065^{* *}(0.028)$ & $0.037 *(0.022)$ \\
\hline Labor days on land preparation & 7.22 & 6.80 & 7.21 & $0.005(0.666)$ & $-0.402(0.628)$ \\
\hline Labor days on sowing & 5.01 & 5.07 & 4.66 & $0.345(0.495)$ & $0.412(0.449)$ \\
\hline Labor days on cultivation & 23.80 & 24.47 & 21.00 & $2.904(2.238)$ & $3.495^{*}(2.087)$ \\
\hline Labor days on harvesting & 9.96 & 10.19 & 10.32 & $-0.349(0.905)$ & $-0.111(0.930)$ \\
\hline Total labor days on farm work & 45.98 & 46.53 & 43.20 & $2.905(3.510)$ & $3.394(3.327)$ \\
\hline Cost of hiring farm labor (birr) & 63.40 & 84.92 & 68.18 & $-4.764(18.209)$ & $16.925(19.136)$ \\
\hline Total value of farm output (birr) & 1908.57 & 2018.68 & 1862.68 & $48.652(159.700)$ & $157.749(177.467)$ \\
\hline \multicolumn{6}{|l|}{ Household finance } \\
\hline Off-farm labor income (birr) & 692.49 & 510.41 & 632.62 & 49.209 (106.945) & $-131.070(93.651)$ \\
\hline Business income (birr) & 664.77 & 572.76 & 523.54 & $140.881(172.323)$ & $50.601(158.695)$ \\
\hline Livestock value (birr) & 5284.60 & 5326.55 & 6013.93 & $-717.254(468.781)$ & $-683.398(485.157)$ \\
\hline Productive assets (birr) & 509.19 & 488.34 & 535.78 & $-26.563(57.164)$ & $-46.845(57.036)$ \\
\hline Cash savings (birr) & 511.20 & 399.87 & 393.84 & 117.065 (178.299) & 7.060 (179.179) \\
\hline Health expenses (birr) & 41.59 & 95.27 & 100.30 & $-58.633^{*}(29.976)$ & $-4.846(33.967)$ \\
\hline Education expenses (birr) & 268.30 & 255.14 & 281.97 & $-13.462(24.759)$ & $-26.368(24.192)$ \\
\hline Private transfer in (birr) & 328.72 & 328.04 & 440.59 & $-111.556(138.857)$ & $-111.385(138.434)$ \\
\hline Private transfer out (birr) & 45.34 & 138.94 & 77.94 & $-32.516(26.639)$ & $61.201(72.874)$ \\
\hline Observations & 384 & 386 & 379 & & \\
\hline
\end{tabular}

Data source: Authors' survey.

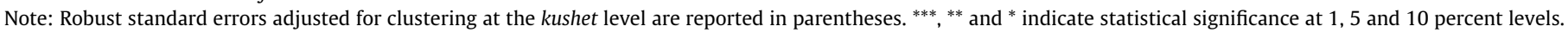

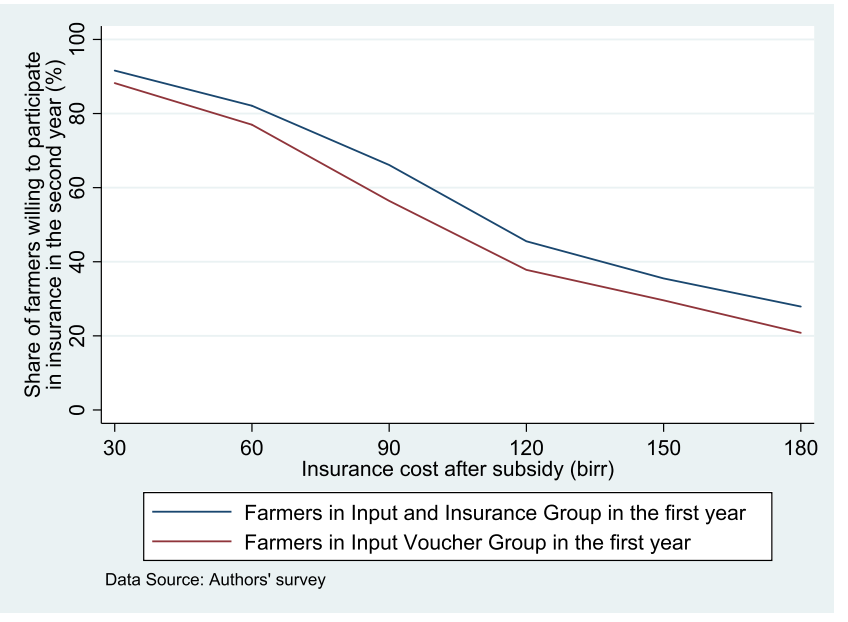

Fig. 2. Share of farmers willing to participate in insurance in the second year.

were small, however. The point estimates of the effect range from 3.38 to 9.68 percentage points. Nonetheless, our results contrast with those found in Ahmed, McIntosh, and Sarris (2017), who demonstrate that initial premium subsidies do not promote future uptake. Fig. 2 further presents the demand for insurance graphically.

Overall, our results show that despite the high level of vulnerability to rainfall risk, a majority of the PSNP farmers would not take up insurance unless they were provided with generous subsidies. It is also unlikely that initially providing generous subsidies to promote the experience of insurance, then reducing the subsidies to improve the financial sustainability, is a cost-effective way to increase insurance adoption.

Going further, we estimate a richer set of the determinants of farmers' willingness in insurance participation. Our model is

$I_{i j K S E C O N D}=a_{0}+a_{1} * I_{i j k F I R S T}+a_{2} * X_{i j k B A S E}+\mu_{k}+e_{i j k S E C O N D}$,

where $I_{i j k S E C O N D}$ is an indicator variable such that farmer $i$ in hamlet community $j$ and village $k$ reported willingness to participate in insurance in the final round of the choice experiment. $I_{i j k F I R S T}$ is an indicator variable such that the farmer was in the input and insurance group in the first year. The comparison group were farmers in the input voucher group, with double the voucher value but no experience of insurance. $X_{i j k B A S E}$ is a vector that includes various farmer characteristics in the baseline. $\mu_{k}$ is the set of village dummies for controlling time-invariant heterogeneities across the villages. We analyze the willingness in insurance participation according to differing levels of subsidy, fitting a linear probability 
Table 2

Willingness on insurance participation by subsidized insurance cost among PSNP farmers in the second-year experiment.

\begin{tabular}{|c|c|c|c|c|}
\hline \multirow{2}{*}{$\begin{array}{l}\text { Insurance cost after } \\
\text { subsidy }\end{array}$} & \multicolumn{4}{|c|}{ Share of farmers willing to participate in insurance in the second year (Percent) } \\
\hline & $\begin{array}{l}\text { All farmers treated in the } \\
\text { first year } \\
(1)\end{array}$ & $\begin{array}{l}\text { Only farmers in the Input and Insurance group in } \\
\text { the first year } \\
\text { (2) }\end{array}$ & $\begin{array}{l}\text { Only farmers in the Input Voucher Group in } \\
\text { the first year } \\
\text { (3) }\end{array}$ & $\begin{array}{l}\text { Differences } \\
(2)-(3)\end{array}$ \\
\hline 30 birr ( $90 \%$ subsidy) & 89.92 & 91.6 & 88.22 & $3.38(2.22)$ \\
\hline 60 birr ( $80 \%$ subsidy) & 79.56 & 82.11 & 76.99 & $\begin{array}{l}5.12^{*} \\
(2.97)\end{array}$ \\
\hline 90 birr (70\% subsidy) & 61.31 & 66.12 & 56.44 & $\begin{array}{l}9.68^{* * *} \\
(3.58)\end{array}$ \\
\hline $\begin{array}{l}120 \text { birr ( } 60 \% \\
\text { subsidy) }\end{array}$ & 41.69 & 45.53 & 37.81 & $\begin{array}{l}7.72^{* *} \\
(3.63)\end{array}$ \\
\hline $\begin{array}{l}150 \text { birr ( } 50 \% \\
\text { subsidy) }\end{array}$ & 32.56 & 35.5 & 29.59 & $\begin{array}{l}5.91^{*} \\
(3.46)\end{array}$ \\
\hline $\begin{array}{c}180 \text { birr }(40 \% \\
\text { subsidy) }\end{array}$ & 24.39 & 27.91 & 20.82 & $\begin{array}{l}7.09^{* *} \\
(3.16)\end{array}$ \\
\hline Observations & 734 & 369 & 365 & \\
\hline
\end{tabular}

Data source: Authors' survey.

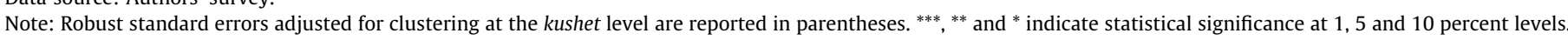

model and estimating robust standard errors with the clustering of hamlet communities.

Table 3 confirms that experiencing free insurance in the first year increased insurance participation willingness in the next year, despite a lack of major payouts. Effect estimates also range from 0.03 to 0.08 and are generally statistically significant (Columns 1 to 6 , Row 1). Older farmers showed less willingness to participate in insurance. The effect is not large, however, as farmers who are 10 years older reported only 0.20 fewer participation choices in the six-round exercise (Column 7). Farmers with a higher level of agricultural productive assets showed a higher overall demand for insurance, suggesting that insurance complements long-term farm investments. In addition, farmers who joined savings and credit associations (Equub) reported 0.68 fewer participation choices in total. It is possible that cash-constrained farmers had to make tradeoffs between participating in communal saving arrangements (which may also in part help farmers better cope with idiosyncratic shocks) and participating in rainfall insurance for coping with covariate shocks. We also find that farmers' willingness to participate in insurance is not statistically associated with their level of risk aversion or time preference. While these results challenge the assumption that farmers hesitant to take up risk, or those more willing to invest for future gains, would have a stronger insurance demand, it is important to note that their PSNP membership may have mitigated their insurance needs.

Overall, we believe that subsidizing insurance is unlikely a financially sustainable way to promote adoption and enable formal ex ante risk management among many poor farmers enrolled in government protection programs. Therefore, it is important to explore mechanisms for promoting insurance among farmers who have a higher willingness to pay. Complementary tools with insurance, such as education, liquidity provision, and work-for-insurance arrangements, may be further explored as alternative strategies to the provision of generous subsidies for promoting uptake and achieving financial sustainability of rainfall finance programs (Madejewicz \& Tsegay, 2013; Madejewicz et al., 2017).

\subsection{Effects of input vouchers and rainfall insurance}

\subsubsection{Difference-in-differences model for the first year}

We estimate the intention-to-treat (ITT) effects of the first-year interventions with a difference-in-differences (DinD) model:

$$
\begin{aligned}
Y_{i j k M I D}-Y_{i j k B A S E}= & a_{0}+a_{1} * V_{i j k F I R S T}+a_{2} * I_{i j k F I R S T}+a_{3} \\
& * X_{i j k B A S E}+\mu_{k}+e_{i j k M I D},
\end{aligned}
$$

where $Y_{i j k M I D}$ and $Y_{i j k B A S E}$ are the outcome variables in the midline and the baseline, respectively. ${ }^{18} V_{i j k F I R S T}$ and $I_{i j k F I R S T}$ show that the farmer was in the input voucher group or the input and insurance group, respectively. $X_{i j k B A S E}$ and $\mu_{k}$ are the set of farmer characteristics and village dummies as in model (1). We estimate robust standard errors with the clustering of hamlets.

\subsubsection{Instrumental variable estimation models}

We further consider intervention status in both the first and the second year of the study to evaluate the cumulative effects of the programs:

$$
\begin{gathered}
Y_{i j k E N D}-Y_{i j k B A S E}=a_{0}+a_{1} * V_{i j k F I R S T} \times V_{i j k S E C O N D}+a_{2} * I_{i j k F I R S T} \\
\times V_{i j k S E C O N D} \\
+a_{3} * V_{i j k F I R S T} \times I_{i j k S E C O N D}+a_{4} * I_{i j k F I R S T} \times I_{i j k S E C O N D} \\
+a_{5} * X_{i j k B A S E}+\mu_{k}+e_{i j k E N D}
\end{gathered}
$$

Here, $Y_{i j k E N D}$ and $Y_{i j k B A S E}$ are outcome variables in the endline and the baseline, respectively. $V_{i j k F I R S T}$ and $I_{i j k F I R S T}$ are defined already in model (2). To simplify presentation and interpretation, we define $V_{i j K S E C O N D}$ and $I_{i j K S E C O N D}$ somewhat differently. Here, $V_{i j k S E C O N D}$ represents that the farmer had received a standard input voucher in the second year, and this is true for all farmers who participated in the second-year choice experiment. $I_{i j k S E C O N D}$ represents the insurance participation in the second year which is jointly determined by the farmer's final decisions in the choice experiment and the randomized subsidy level. We interact the

\footnotetext{
18 Given the humble size of the values of our intervention packages, we prefer to use a difference-in-differences model instead of a simple differencing model to more preciously estimate the effects of our intervention by removing possible differences in the point estimates of the outcome variables in the baseline. We have also conducted further analysis using a simple differencing model with only strata fixed effects but not any other covariates. The results are similar and are slightly less precise. Therefore, we do not report results obtained from a simple differencing model for the sake of brevity.
} 
Table 3

Determinants of willingness on insurance participation by subsidized insurance cost among PSNP farmers in the second-year choice experiment.

\begin{tabular}{|c|c|c|c|c|c|c|c|}
\hline & \multicolumn{6}{|c|}{ Willingness on insurance participation by subsidized cost ( $1=$ Yes; $0=$ No) } & \multirow{2}{*}{$\begin{array}{l}\text { Number of participation } \\
\text { choices }(0-6)\end{array}$} \\
\hline & $\begin{array}{l}30 \text { birr ( } 90 \% \\
\text { subsidy) } \\
(1)\end{array}$ & $\begin{array}{l}60 \text { birr }(80 \% \\
\text { subsidy) } \\
(2)\end{array}$ & $\begin{array}{l}90 \text { birr ( } 70 \% \\
\text { subsidy) } \\
(3)\end{array}$ & $\begin{array}{l}120 \text { birr ( } 60 \% \\
\text { subsidy) } \\
(4)\end{array}$ & $\begin{array}{l}150 \text { birr ( } 50 \% \\
\text { subsidy) } \\
(5)\end{array}$ & $\begin{array}{l}180 \text { birr ( } 40 \% \\
\text { subsidy) } \\
(6)\end{array}$ & \\
\hline $\begin{array}{l}\text { Input and Insurance in Year } 1 \\
\quad(1=\text { Yes; } 0=\text { No })\end{array}$ & $\begin{array}{l}0.03^{* *} \\
(0.01)\end{array}$ & $\begin{array}{l}0.04^{* *} \\
(0.02)\end{array}$ & $\begin{array}{l}0.08^{* * *} \\
(0.03)\end{array}$ & $\begin{array}{l}0.06^{* *} \\
(0.03)\end{array}$ & $\begin{array}{l}0.04 \\
(0.03)\end{array}$ & $\begin{array}{l}0.06^{* *} \\
(0.02)\end{array}$ & $\begin{array}{l}0.31^{* * *} \\
(0.10)\end{array}$ \\
\hline $\begin{array}{l}\text { Head gender }(1=\text { Female; } \\
\quad 0=\text { Male })\end{array}$ & $\begin{array}{l}-0.00 \\
(0.03)\end{array}$ & $\begin{array}{l}-0.05 \\
(0.04)\end{array}$ & $\begin{array}{l}-0.02 \\
(0.05)\end{array}$ & $\begin{array}{l}-0.05 \\
(0.05)\end{array}$ & $\begin{array}{l}-0.03 \\
(0.05)\end{array}$ & $\begin{array}{l}-0.02 \\
(0.04)\end{array}$ & $\begin{array}{l}-0.18 \\
(0.20)\end{array}$ \\
\hline Head age (years) & $\begin{array}{l}-0.00 \\
(0.00)\end{array}$ & $\begin{array}{l}-0.00 \\
(0.00)\end{array}$ & $\begin{array}{l}-0.00 \\
(0.00)\end{array}$ & $\begin{array}{l}-0.00^{* *} \\
(0.00)\end{array}$ & $\begin{array}{l}-0.00^{* *} \\
(0.00)\end{array}$ & $\begin{array}{l}-0.00^{* * *} \\
(0.00)\end{array}$ & $\begin{array}{l}-0.02^{* * *} \\
(0.01)\end{array}$ \\
\hline Head years of education & $\begin{array}{l}-0.00 \\
(0.00)\end{array}$ & $\begin{array}{l}-0.01 \\
(0.01)\end{array}$ & $\begin{array}{l}0.00 \\
(0.01)\end{array}$ & $\begin{array}{l}0.01 \\
(0.01)\end{array}$ & $\begin{array}{l}0.02^{*} \\
(0.01)\end{array}$ & $\begin{array}{l}0.01 \\
(0.01)\end{array}$ & $\begin{array}{l}0.03 \\
(0.03)\end{array}$ \\
\hline Household size & $\begin{array}{l}0.00 \\
(0.01)\end{array}$ & $\begin{array}{l}-0.01 \\
(0.01)\end{array}$ & $\begin{array}{l}-0.00 \\
(0.01)\end{array}$ & $\begin{array}{l}-0.01 \\
(0.01)\end{array}$ & $\begin{array}{l}-0.01 \\
(0.01)\end{array}$ & $\begin{array}{l}-0.00 \\
(0.01)\end{array}$ & $\begin{array}{l}-0.03 \\
(0.04)\end{array}$ \\
\hline Size of farmland (timad) & $\begin{array}{l}0.00 \\
(0.01)\end{array}$ & $\begin{array}{l}-0.01 \\
(0.01)\end{array}$ & $\begin{array}{l}-0.00 \\
(0.01)\end{array}$ & $\begin{array}{l}-0.02 \\
(0.01)\end{array}$ & $\begin{array}{l}-0.01 \\
(0.01)\end{array}$ & $\begin{array}{l}-0.01 \\
(0.01)\end{array}$ & $\begin{array}{l}-0.04 \\
(0.05)\end{array}$ \\
\hline Livestock value ('000 birr) & $\begin{array}{l}0.00 \\
(0.00)\end{array}$ & $\begin{array}{l}-0.00 \\
(0.00)\end{array}$ & $\begin{array}{l}-0.00 \\
(0.00)\end{array}$ & $\begin{array}{l}-0.01^{*} \\
(0.00)\end{array}$ & $\begin{array}{l}-0.00 \\
(0.00)\end{array}$ & $\begin{array}{l}-0.00 \\
(0.00)\end{array}$ & $\begin{array}{l}-0.01 \\
(0.01)\end{array}$ \\
\hline Productive assets ('000 birr) & $\begin{array}{l}0.01 \\
(0.01)\end{array}$ & $\begin{array}{l}-0.00 \\
(0.02)\end{array}$ & $\begin{array}{l}0.02 \\
(0.02)\end{array}$ & $\begin{array}{l}0.03^{*} \\
(0.02)\end{array}$ & $\begin{array}{l}-0.01 \\
(0.02)\end{array}$ & $\begin{array}{l}0.01 \\
(0.02)\end{array}$ & $\begin{array}{l}0.06 \\
(0.08)\end{array}$ \\
\hline Total labor days on farm work & $\begin{array}{l}-0.00 \\
(0.00)\end{array}$ & $\begin{array}{l}0.00 \\
(0.00)\end{array}$ & $\begin{array}{l}0.00 \\
(0.00)\end{array}$ & $\begin{array}{l}0.00^{* *} \\
(0.00)\end{array}$ & $\begin{array}{l}0.00^{*} \\
(0.00)\end{array}$ & $\begin{array}{l}0.00^{*} \\
(0.00)\end{array}$ & $\begin{array}{l}0.00 \\
(0.00)\end{array}$ \\
\hline $\begin{array}{l}\text { Mahber membership (1 = Yes; } \\
\quad 0=\text { No) }\end{array}$ & $\begin{array}{l}-0.00 \\
(0.02)\end{array}$ & $\begin{array}{l}0.03 \\
(0.03)\end{array}$ & $\begin{array}{l}0.01 \\
(0.04)\end{array}$ & $\begin{array}{l}-0.03 \\
(0.04)\end{array}$ & $\begin{array}{l}-0.01 \\
(0.03)\end{array}$ & $\begin{array}{l}-0.01 \\
(0.03)\end{array}$ & $\begin{array}{l}-0.01 \\
(0.14)\end{array}$ \\
\hline $\begin{array}{l}\text { Iddir membership ( } 1 \text { = Yes; } \\
\quad 0=\mathrm{No})\end{array}$ & $\begin{array}{l}0.01 \\
(0.03)\end{array}$ & $\begin{array}{l}-0.01 \\
(0.04)\end{array}$ & $\begin{array}{l}0.02 \\
(0.05)\end{array}$ & $\begin{array}{l}0.06 \\
(0.04)\end{array}$ & $\begin{array}{l}0.05 \\
(0.04)\end{array}$ & $\begin{array}{l}0.03 \\
(0.04)\end{array}$ & $\begin{array}{l}0.15 \\
(0.18)\end{array}$ \\
\hline $\begin{array}{l}\text { Equub membership }(1=\text { Yes; } \\
\quad 0=\text { No) }\end{array}$ & $\begin{array}{l}-0.01 \\
(0.05)\end{array}$ & $\begin{array}{l}-0.08 \\
(0.07)\end{array}$ & $\begin{array}{l}-0.21^{* * *} \\
(0.07)\end{array}$ & $\begin{array}{l}-0.17^{* *} \\
(0.06)\end{array}$ & $\begin{array}{l}-0.11^{*} \\
(0.06)\end{array}$ & $\begin{array}{l}-0.09^{* *} \\
(0.05)\end{array}$ & $\begin{array}{l}-0.68^{* *} \\
(0.28)\end{array}$ \\
\hline $\begin{array}{l}\text { Risk preference measure ( } 0 \text { to } \\
\text { 12) }\end{array}$ & $\begin{array}{l}0.00 \\
(0.00)\end{array}$ & $\begin{array}{l}-0.00 \\
(0.00)\end{array}$ & $\begin{array}{l}-0.00 \\
(0.00)\end{array}$ & $\begin{array}{l}-0.01 \\
(0.00)\end{array}$ & $\begin{array}{l}-0.00 \\
(0.00)\end{array}$ & $\begin{array}{l}-0.01^{*} \\
(0.00)\end{array}$ & $\begin{array}{l}-0.02 \\
(0.02)\end{array}$ \\
\hline $\begin{array}{l}\text { Time preference measure ( } 0 \text { to } \\
\text { 8) }\end{array}$ & $\begin{array}{l}0.00 \\
(0.00)\end{array}$ & $\begin{array}{l}0.00 \\
(0.01)\end{array}$ & $\begin{array}{l}0.01 \\
(0.01)\end{array}$ & $\begin{array}{l}0.00 \\
(0.01)\end{array}$ & $\begin{array}{l}-0.00 \\
(0.01)\end{array}$ & $\begin{array}{l}0.00 \\
(0.01)\end{array}$ & $\begin{array}{l}0.01 \\
(0.02)\end{array}$ \\
\hline Numeracy score (0 to 3 ) & $\begin{array}{l}0.00 \\
(0.01)\end{array}$ & $\begin{array}{l}0.01 \\
(0.02)\end{array}$ & $\begin{array}{l}0.00 \\
(0.02)\end{array}$ & $\begin{array}{l}-0.00 \\
(0.02)\end{array}$ & $\begin{array}{l}-0.02 \\
(0.02)\end{array}$ & $\begin{array}{l}-0.01 \\
(0.01)\end{array}$ & $\begin{array}{l}-0.02 \\
(0.07)\end{array}$ \\
\hline Village dummies & $\mathrm{Y}$ & $\mathrm{Y}$ & $\mathrm{Y}$ & $\mathrm{Y}$ & $\mathrm{Y}$ & $\mathrm{Y}$ & $\mathrm{Y}$ \\
\hline Observations & 733 & 733 & 733 & 733 & 733 & 733 & 733 \\
\hline$R^{2}$ & 0.19 & 0.12 & 0.14 & 0.19 & 0.18 & 0.18 & 0.21 \\
\hline
\end{tabular}

Data source: Authors' survey.

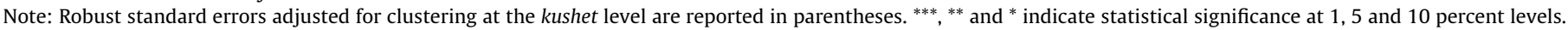

second-year interaction variables with those constructed for the first year to represent the farmer's intervention status over the two years. $^{19}$

We adopt an instrumental variable (IV) estimation approach as insurance participation in the second year, $I_{i j K S E C O N D}$, was voluntary. We develop instruments using a set of random variables constructed from the first-year intervention status, $V_{i j k F I R S T}$ and $I_{i j k F I R S T}$, and the set of binary variables representing second-year insurance subsidy rates, $P_{i j k S E C O N D}$. These variables, namely $V_{i j k F I R S T} \times P_{i j k S E C O N D}$ and $I_{i j k F I R S T} \times P_{i j K S E C O N D}$, capture our random assignments to the farmers in both study years and are strong instruments for the endogenous variables (see further results in Appendix Table 3). ${ }^{20}$

\footnotetext{
19 For example, $V_{i j k F I R S T} \times V_{i j k S E C O N D}$ represents farmers who were in the input voucher group in the first year and also received input vouchers in the second year. $I_{i j k F I R S T} \times V_{i j k S E C O N D}$ represents farmers who were in the input and insurance group in the first year and received input vouchers in the second year. $V_{i j k F I R S T} \times I_{i j k S E C O N D}$ represents farmers who were in the input voucher group in the first year and also chose to participate in insurance in the second year. Finally, $I_{i j k F I R S T} \times I_{i j k S E C O N D}$ represents farmers who were in the input and insurance group in the first year and also chose to participate in insurance in the second year.

20 Due to the high level of price sensitivity in the insurance demand, our sets of instruments are strong, exogenous predictors of farmers' insurance participation decisions in the second year. The F-statistic of the instruments for the endogenous variable $V_{i j k F I R S T} \times I_{i j k S E C O N D}$ is 1381.40 and the $F$-statistic of the instruments for $I_{i j k F I R S T}$ $\times I_{i j K S E C O N D}$ is 2140.98 . The Kleibergen-Paap Wald rk F-statistic is also high, 1267.25. Therefore, we easily reject the null hypothesis that our sets of instruments are weak.
}

\subsubsection{Effects on the purchase and use of agricultural inputs}

We first analyze the effects of the interventions on input purchase (Table 4). ${ }^{21}$ In the first year, the two intervention packages statistically raised the purchase of seeds by 101 birr and 57 birr (Column 1). Rainfall insurance bundled with input vouchers did not increase the purchase of seeds statistically. Results of the two-year effects also show that only current voucher transfers had a statistically significant effect on current purchase of seeds. Farmers who obtained additional insurance in the second year, regardless of their first-year status, did not purchase more seeds.

We find large and significant effects from the second-year vouchers on the purchase of fertilizers, at 128 birr and 146 birr (Column 2). Farmers receiving a 300-birr input voucher in the second year thus allocated nearly half of the voucher value to purchasing fertilizers. Taking this together with the first-year results, we find that when cash constraints were relaxed over two years, farmers first prioritized seeds, a direct input, and then raised fertilizers, a complementary input (Beaman, Karlan, Thuysbaert, \& Udry, 2013). The insurance-voucher bundle did not significantly increase fertilizer purchases in both years. The effects of the two interventions on tools, herbicides and pesticides were small (Column 3 and 4), in line with our understanding of agriculture in the region.

To address concerns about possible storage, resale, or sharing of inputs obtained from the vouchers, we further analyze whether the

\footnotetext{
21 We do not have baseline data for input purchases and cannot take the first difference in these outcomes
} 
Table 4

Effects of input voucher and rainfall insurance on the purchase and usage of agricultural inputs.

\begin{tabular}{|c|c|c|c|c|c|c|c|c|c|c|}
\hline & $\begin{array}{l}\text { Purchase } \\
\text { of seeds } \\
\text { (birr) } \\
\text { (1) }\end{array}$ & $\begin{array}{l}\text { Purchase of } \\
\text { chemical } \\
\text { fertilizer } \\
\text { (birr) } \\
\text { (2) }\end{array}$ & $\begin{array}{l}\text { Purchase } \\
\text { of tools } \\
\text { (birr) } \\
(3)\end{array}$ & $\begin{array}{l}\text { Purchase of } \\
\text { herbicide and } \\
\text { pesticide (birr) } \\
\text { (4) }\end{array}$ & $\begin{array}{l}\text { Purchase } \\
\text { of all } \\
\text { inputs } \\
\text { (birr) } \\
\text { (5) }\end{array}$ & $\begin{array}{l}\text { Usage of } \\
\text { seeds } \\
\text { (birr) } \\
\text { (6) }\end{array}$ & $\begin{array}{l}\text { Usage of } \\
\text { chemical } \\
\text { fertilizer } \\
\text { (birr) } \\
\text { (7) }\end{array}$ & $\begin{array}{l}\text { Usage of } \\
\text { compost } \\
\text { fertilizer } \\
\text { (birr) } \\
\text { (8) }\end{array}$ & $\begin{array}{l}\text { Usage of } \\
\text { herbicide and } \\
\text { pesticide } \\
\text { (birr) } \\
\text { (9) }\end{array}$ & $\begin{array}{l}\text { Total } \\
\text { agricultural } \\
\text { input cost } \\
\text { (birr) } \\
(10)\end{array}$ \\
\hline $\begin{array}{l}\text { PANEL A (ITT-Fixed } \\
\text { effects) }\end{array}$ & Midline & & & & & Midline - & Baseline & & & \\
\hline $\begin{array}{l}\text { Input Voucher in } \\
\text { Year } 1\end{array}$ & $\begin{array}{l}101.19^{* * *} \\
(36.32)\end{array}$ & $\begin{array}{l}41.44 \\
(57.65)\end{array}$ & $\begin{array}{l}11.43^{*} \\
(6.49)\end{array}$ & $\begin{array}{l}2.97 \\
(3.91)\end{array}$ & $\begin{array}{l}157.03^{*} \\
(84.97)\end{array}$ & $\begin{array}{l}123.09^{* *} \\
(52.95)\end{array}$ & $\begin{array}{l}43.15 \\
(56.38)\end{array}$ & $\begin{array}{l}44.05 \\
(54.66)\end{array}$ & $\begin{array}{l}-1.33 \\
(5.00)\end{array}$ & $\begin{array}{l}208.96^{* *} \\
(101.41)\end{array}$ \\
\hline $\begin{array}{l}\text { Input and Insurance } \\
\text { in Year } 1\end{array}$ & $\begin{array}{l}57.15^{*} \\
(31.44)\end{array}$ & $\begin{array}{l}14.38 \\
(44.88)\end{array}$ & $\begin{array}{l}4.67 \\
(4.93)\end{array}$ & $\begin{array}{l}-0.24 \\
(3.72)\end{array}$ & $\begin{array}{l}75.97 \\
(74.85)\end{array}$ & $\begin{array}{l}-15.28 \\
(47.77)\end{array}$ & $\begin{array}{l}7.20 \\
(46.36)\end{array}$ & $\begin{array}{l}-29.76 \\
(50.38)\end{array}$ & $\begin{array}{l}3.38 \\
(4.02)\end{array}$ & $\begin{array}{l}-34.46 \\
(93.82)\end{array}$ \\
\hline $\begin{array}{l}\text { Farmer } \\
\text { characteristics }\end{array}$ & $\mathrm{Y}$ & $\mathrm{Y}$ & $\mathrm{Y}$ & $\mathrm{Y}$ & $\mathrm{Y}$ & $\mathrm{Y}$ & $\mathrm{Y}$ & $\mathrm{Y}$ & $\mathrm{Y}$ & $\mathrm{Y}$ \\
\hline Village dummies & $\mathrm{Y}$ & $\mathrm{Y}$ & $\mathrm{Y}$ & $\mathrm{Y}$ & $\mathrm{Y}$ & $\mathrm{Y}$ & $\mathrm{Y}$ & $\mathrm{Y}$ & $\mathrm{Y}$ & $\mathrm{Y}$ \\
\hline$N$ & 1149 & 1149 & 1149 & 1149 & 1149 & 1149 & 1149 & 1149 & 1149 & 1149 \\
\hline$R^{2}$ & 0.22 & 0.34 & 0.12 & 0.24 & 0.33 & 0.10 & 0.07 & 0.07 & 0.09 & 0.09 \\
\hline $\begin{array}{l}\text { Mean for control } \\
\quad \text { (Midline) }\end{array}$ & 222.01 & 777.71 & 17.87 & 16.16 & 1033.75 & 680.36 & 804.25 & 233.93 & 18.63 & 1737.18 \\
\hline $\begin{array}{l}\text { Difference in effect } \\
\text { estimates }\end{array}$ & $\begin{array}{l}44.03 \\
(32.34)\end{array}$ & $\begin{array}{l}27.05 \\
(46.56)\end{array}$ & $\begin{array}{l}6.76 \\
(6.00)\end{array}$ & $\begin{array}{l}3.20 \\
(4.56)\end{array}$ & $\begin{array}{l}81.06 \\
(77.20)\end{array}$ & $\begin{array}{l}138.37^{* * *} \\
(46.51)\end{array}$ & $\begin{array}{l}35.94 \\
(50.84)\end{array}$ & $\begin{array}{l}73.82 \\
(59.72)\end{array}$ & $\begin{array}{l}-4.71 \\
(5.16)\end{array}$ & $\begin{array}{l}243.42^{* *} \\
(109.29)\end{array}$ \\
\hline PANEL B (IV-2SLS) & Endline & & & & & Endline - & Baseline & & & \\
\hline $\begin{array}{l}\text { Input Voucher in } \\
\text { Year } 2 \times \text { Input } \\
\text { Voucher in Year } 1\end{array}$ & $\begin{array}{l}67.80^{* *} \\
(33.55)\end{array}$ & $\begin{array}{l}127.82^{* *} \\
(52.33)\end{array}$ & $\begin{array}{l}-1.66 \\
(6.48)\end{array}$ & $\begin{array}{l}2.34 \\
(3.78)\end{array}$ & $\begin{array}{l}196.30^{* * *} \\
(75.95)\end{array}$ & $\begin{array}{l}-0.32 \\
(57.40)\end{array}$ & $\begin{array}{l}168.62^{* *} \\
(72.19)\end{array}$ & $\begin{array}{l}-53.68 \\
(69.63)\end{array}$ & $\begin{array}{l}4.40 \\
(6.42)\end{array}$ & $\begin{array}{l}119.02 \\
(129.62)\end{array}$ \\
\hline $\begin{array}{l}\text { Input Voucher in } \\
\text { Year } 2 \times \text { Input } \\
\text { and Insurance in } \\
\text { Year } 1\end{array}$ & $\begin{array}{l}46.68 \\
(29.71)\end{array}$ & $\begin{array}{l}146.04^{* * *} \\
(54.68)\end{array}$ & $\begin{array}{l}-12.82^{*} \\
(6.68)\end{array}$ & $\begin{array}{l}-6.81^{*} \\
(3.76)\end{array}$ & $\begin{array}{l}173.09^{* *} \\
(72.06)\end{array}$ & $\begin{array}{l}33.79 \\
(56.30)\end{array}$ & $\begin{array}{l}140.50 * \\
(56.68)\end{array}$ & $\begin{array}{l}30.05 \\
(58.71)\end{array}$ & $\begin{array}{l}-3.37 \\
(4.79)\end{array}$ & $\begin{array}{l}200.97^{*} \\
(119.36)\end{array}$ \\
\hline $\begin{array}{l}\text { Insurance in Year } \\
2 \times \text { Input } \\
\text { Voucher in Year } 1\end{array}$ & $\begin{array}{l}7.51 \\
(44.74)\end{array}$ & $\begin{array}{l}-56.08 \\
(68.90)\end{array}$ & $\begin{array}{l}-2.43 \\
(7.65)\end{array}$ & $\begin{array}{l}-7.90^{*} \\
(4.44)\end{array}$ & $\begin{array}{l}-58.91 \\
(105.39)\end{array}$ & $\begin{array}{l}114.57 \\
(82.35)\end{array}$ & $\begin{array}{l}-99.33 \\
(99.16)\end{array}$ & $\begin{array}{l}2.81 \\
(78.41)\end{array}$ & $\begin{array}{l}-13.39 \\
(9.95)\end{array}$ & $\begin{array}{l}4.66 \\
(163.14)\end{array}$ \\
\hline $\begin{array}{l}\text { Insurance in Year } \\
2 \times \text { Input and } \\
\text { Insurance in Year } \\
1\end{array}$ & $\begin{array}{l}5.70 \\
(25.35)\end{array}$ & $\begin{array}{l}5.45 \\
(47.39)\end{array}$ & $\begin{array}{l}11.50 \\
(8.45)\end{array}$ & $\begin{array}{l}8.41^{*} \\
(4.69)\end{array}$ & $\begin{array}{l}31.06 \\
(71.35)\end{array}$ & $\begin{array}{l}-46.04 \\
(50.43)\end{array}$ & $\begin{array}{l}-40.06 \\
(59.29)\end{array}$ & $\begin{array}{l}-172.51^{* *} \\
(73.96)\end{array}$ & $\begin{array}{l}6.11 \\
(6.04)\end{array}$ & $\begin{array}{l}-252.50^{*} \\
(134.72)\end{array}$ \\
\hline $\begin{array}{l}\text { Farmer } \\
\quad \text { characteristics }\end{array}$ & $\mathrm{Y}$ & $\mathrm{Y}$ & $\mathrm{Y}$ & $\mathrm{Y}$ & $\mathrm{Y}$ & $\mathrm{Y}$ & $\mathrm{Y}$ & $\mathrm{Y}$ & $\mathrm{Y}$ & $\mathrm{Y}$ \\
\hline Village dummies & $\mathrm{Y}$ & $\mathrm{Y}$ & $\mathrm{Y}$ & $\mathrm{Y}$ & $\mathrm{Y}$ & $\mathrm{Y}$ & $\mathrm{Y}$ & $\mathrm{Y}$ & $\mathrm{Y}$ & $\mathrm{Y}$ \\
\hline$N$ & 1099 & 1099 & 1099 & 1099 & 1099 & 1099 & 1099 & 1099 & 1099 & 1099 \\
\hline$R^{2}$ & 0.26 & 0.33 & 0.15 & 0.22 & 0.35 & 0.22 & 0.08 & 0.08 & 0.08 & 0.14 \\
\hline $\begin{array}{l}\text { Mean for control } \\
\quad \text { (Endline) }\end{array}$ & 198.99 & 698.66 & 33.15 & 16.49 & 947.29 & 650.04 & 727.30 & 167.01 & 21.70 & 1566.06 \\
\hline
\end{tabular}

Data source: Authors' survey.

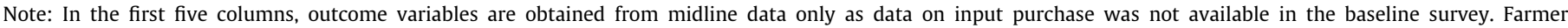

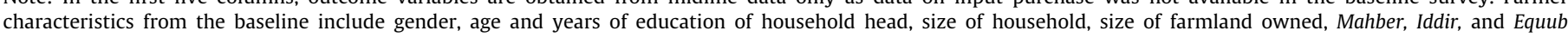

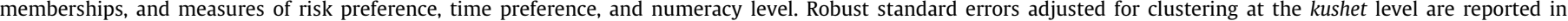
parentheses. ${ }^{* *},{ }^{* *}$, and ${ }^{*}$ indicate significance at the 1,5 and 10 percent levels.

interventions had brought positive effects on their use of inputs. In general, the findings on input purchase and use are similar. In the first year, the pure input voucher intervention increased the use of seeds by 123 birr significantly (Column 6). In the following year, the provision of input vouchers also significantly increased the use of fertilizers by about 150 birr (Column 7). However, in the first year, insurance-voucher bundle virtually brought no effects on the use of seeds, which contrasts with the effects of the first intervention.

Overall, we find that subsidizing inputs with vouchers fulfills the promise of stimulating agricultural activities. As the total cost of agricultural input increases by 209 birr (Column 10), the efficiency rate of providing liquidity on agricultural investments is about 50 percent. Subsidized insurance bundled with a reduced amount of input vouchers is generally not effective in increasing input purchase or use. Importantly, the estimated effect of the input voucher intervention on the total agricultural input cost is 243 birr higher than the estimated effect of the input and insurance intervention bundle (statistically significant at the 5 percent level). While both approaches require government support to reach farmers enrolled in government protection programs, addressing cash and credit constraint through subsidizing inputs can produce more immediate effects than alleviating ex ante risk constraint. Further research is needed to identify strategies that can better integrate complementary activities and incentivize behavior changes for improving the responsiveness of droughtprone farmers to the relaxation of risk constraints.

\subsubsection{Effects on land and labor}

We next explore the effects of the interventions on land and labor (Table 5). In the first year, the pure input voucher intervention significantly increased the amount of farmland on which farmers practiced sharecropping on others' land by 0.09 timad. The intervention also reduced the amount of farmland they rented out to others for sharecropping or left fallow by 0.12 timad and 0.07 timad, respectively. The sum of these arrangements was 0.29 timad, roughly $15 \%$ of the average farmland ownership in our sample. In further analysis, we further find evidence that some farmers who received vouchers in the second year increased the amount of farmland cultivated.

Interestingly, there is some evidence that the insurancevoucher bundle increased the scale of farming. In the first year, 
Table 5

Effects of input voucher and rainfall insurance on farm land and labor.

\begin{tabular}{|c|c|c|c|c|c|c|c|c|c|c|}
\hline & $\begin{array}{l}\text { Farmland } \\
\text { sharing in } \\
\text { (timad) } \\
\text { (1) }\end{array}$ & $\begin{array}{l}\text { Farmland } \\
\text { sharing out } \\
\text { (timad) } \\
\text { (2) }\end{array}$ & $\begin{array}{l}\text { Farmland } \\
\text { fallow } \\
\text { (timad) } \\
\text { (3) }\end{array}$ & $\begin{array}{l}\text { Farmland } \\
\text { cultivated } \\
\text { (timad) } \\
(4)\end{array}$ & $\begin{array}{l}\text { Labor days } \\
\text { on land } \\
\text { preparation } \\
\text { (5) }\end{array}$ & $\begin{array}{l}\text { Labor } \\
\text { days on } \\
\text { sowing } \\
(6)\end{array}$ & $\begin{array}{l}\text { Labor days } \\
\text { on } \\
\text { cultivation } \\
(7)\end{array}$ & $\begin{array}{l}\text { Labor } \\
\text { days on } \\
\text { harvesting } \\
(8)\end{array}$ & $\begin{array}{l}\text { Total labor } \\
\text { days on } \\
\text { farm work } \\
\text { (9) }\end{array}$ & $\begin{array}{l}\text { Cost of } \\
\text { hiring farm } \\
\text { labor (birr) } \\
(10)\end{array}$ \\
\hline \multicolumn{5}{|l|}{ PANEL A (ITT-Fixed effects) } & \multicolumn{6}{|c|}{ Midline - Baseline } \\
\hline Input Voucher in Year 1 & $\begin{array}{l}0.09^{* *} \\
(0.05)\end{array}$ & $\begin{array}{l}-0.12^{* *} \\
(0.05)\end{array}$ & $\begin{array}{l}-0.07^{*} \\
(0.04)\end{array}$ & $\begin{array}{l}0.29^{* * *} \\
(0.09)\end{array}$ & $\begin{array}{l}-1.34^{* *} \\
(0.58)\end{array}$ & $\begin{array}{l}-0.81^{* *} \\
(0.39)\end{array}$ & $\begin{array}{l}-0.17 \\
(2.25)\end{array}$ & $\begin{array}{l}-0.54 \\
(0.98)\end{array}$ & $\begin{array}{l}-2.86 \\
(3.30)\end{array}$ & $\begin{array}{l}79.47^{*} \\
(43.62)\end{array}$ \\
\hline $\begin{array}{l}\text { Input and Insurance in } \\
\quad \text { Year } 1\end{array}$ & $\begin{array}{l}0.17^{* * *} \\
(0.05)\end{array}$ & $\begin{array}{l}-0.04 \\
(0.05)\end{array}$ & $\begin{array}{l}-0.05 \\
(0.03)\end{array}$ & $\begin{array}{l}0.26^{* * *} \\
(0.09)\end{array}$ & $\begin{array}{l}-0.57 \\
(0.59)\end{array}$ & $\begin{array}{l}-0.73^{* *} \\
(0.34)\end{array}$ & $\begin{array}{l}-2.30 \\
(2.00)\end{array}$ & $\begin{array}{l}0.05 \\
(0.87)\end{array}$ & $\begin{array}{l}-3.55 \\
(2.87)\end{array}$ & $\begin{array}{l}2.16 \\
(31.97)\end{array}$ \\
\hline Farmer characteristics & $\mathrm{Y}$ & $\mathrm{Y}$ & Y & $\mathrm{Y}$ & $\mathrm{Y}$ & $\mathrm{Y}$ & Y & $\mathrm{Y}$ & Y & Y \\
\hline Village dummies & $\mathrm{Y}$ & $\mathrm{Y}$ & $\mathrm{Y}$ & $\mathrm{Y}$ & $\mathrm{Y}$ & $\mathrm{Y}$ & $\mathrm{Y}$ & $\mathrm{Y}$ & $\mathrm{Y}$ & $\mathrm{Y}$ \\
\hline$N$ & 1149 & 1149 & 1149 & 1149 & 1149 & 1149 & 1149 & 1149 & 1149 & 1149 \\
\hline$R^{2}$ & 0.13 & 0.07 & 0.06 & 0.11 & 0.12 & 0.12 & 0.07 & 0.07 & 0.11 & 0.08 \\
\hline $\begin{array}{l}\text { Mean for control } \\
\text { (Midline) }\end{array}$ & 0.10 & 0.62 & 0.06 & 2.10 & 7.13 & 4.57 & 23.93 & 13.36 & 48.99 & 80.63 \\
\hline $\begin{array}{l}\text { Difference in effect } \\
\text { estimates }\end{array}$ & $\begin{array}{l}-0.08 \\
(0.05)\end{array}$ & $\begin{array}{l}-0.08^{*} \\
(0.05)\end{array}$ & $\begin{array}{l}-0.02 \\
(0.04)\end{array}$ & $0.03(0.07)$ & $-0.77(0.56)$ & $\begin{array}{l}-0.09 \\
(0.39)\end{array}$ & $2.13(2.22)$ & $\begin{array}{l}-0.59 \\
(0.92)\end{array}$ & $0.70(3.15)$ & $\begin{array}{l}77.30^{*} \\
(40.16)\end{array}$ \\
\hline \multicolumn{5}{|l|}{ PANEL B (IV-2SLS) } & \multicolumn{6}{|c|}{ Endline - Baseline } \\
\hline $\begin{array}{l}\text { Input Voucher in Year } \\
2 \times \text { Input Voucher in } \\
\text { Year } 1\end{array}$ & $\begin{array}{l}0.02 \\
(0.06)\end{array}$ & $\begin{array}{l}-0.17^{* *} \\
(0.08)\end{array}$ & $\begin{array}{l}-0.09 * \\
(0.05)\end{array}$ & $\begin{array}{l}0.29^{* *} \\
(0.11)\end{array}$ & $\begin{array}{l}0.04 \\
(0.76)\end{array}$ & $\begin{array}{l}-0.17 \\
(0.59)\end{array}$ & $\begin{array}{l}-5.93^{*} \\
(3.03)\end{array}$ & $\begin{array}{l}-1.32 \\
(1.24)\end{array}$ & $\begin{array}{l}-7.38 \\
(4.66)\end{array}$ & $\begin{array}{l}204.10^{* * * *} \\
(57.28)\end{array}$ \\
\hline $\begin{array}{l}\text { Input Voucher in Year } \\
2 \times \text { Input and } \\
\text { Insurance in Year } 1\end{array}$ & $\begin{array}{l}0.02 \\
(0.07)\end{array}$ & $\begin{array}{l}-0.12 \\
(0.10)\end{array}$ & $\begin{array}{l}-0.01 \\
(0.03)\end{array}$ & $\begin{array}{l}0.15 \\
(0.13)\end{array}$ & $\begin{array}{l}0.65 \\
(0.82)\end{array}$ & $\begin{array}{l}-1.01^{*} \\
(0.54)\end{array}$ & $\begin{array}{l}-2.01 \\
(2.03)\end{array}$ & $\begin{array}{l}-0.30 \\
(1.16)\end{array}$ & $\begin{array}{l}-2.67 \\
(3.22)\end{array}$ & $\begin{array}{l}-1.70 \\
(38.23)\end{array}$ \\
\hline $\begin{array}{l}\text { Insurance in Year } \\
2 \times \text { Input Voucher in } \\
\text { Year } 1\end{array}$ & $\begin{array}{l}-0.07 \\
(0.07)\end{array}$ & $\begin{array}{l}0.11 \\
(0.09)\end{array}$ & $\begin{array}{l}0.05 \\
(0.05)\end{array}$ & $\begin{array}{l}-0.22^{* *} \\
(0.10)\end{array}$ & $\begin{array}{l}-0.91 \\
(0.98)\end{array}$ & $\begin{array}{l}-1.07 \\
(0.76)\end{array}$ & $\begin{array}{l}1.71 \\
(3.47)\end{array}$ & $\begin{array}{l}0.90 \\
(1.64)\end{array}$ & $\begin{array}{l}0.64 \\
(5.52)\end{array}$ & $\begin{array}{l}-72.32 \\
(67.95)\end{array}$ \\
\hline $\begin{array}{l}\text { Insurance in Year } \\
2 \times \text { Input and } \\
\text { Insurance in Year } 1\end{array}$ & $\begin{array}{l}0.00 \\
(0.07)\end{array}$ & $\begin{array}{l}0.08 \\
(0.10)\end{array}$ & $\begin{array}{l}-0.02 \\
(0.04)\end{array}$ & $\begin{array}{l}-0.06 \\
(0.14)\end{array}$ & $\begin{array}{l}0.21 \\
(0.93)\end{array}$ & $\begin{array}{l}0.77 \\
(0.51)\end{array}$ & $\begin{array}{l}-4.50^{*} \\
(2.40)\end{array}$ & $\begin{array}{l}0.88 \\
(1.39)\end{array}$ & $\begin{array}{l}-2.64 \\
(3.72)\end{array}$ & $\begin{array}{l}6.67 \\
(28.99)\end{array}$ \\
\hline Farmer characteristics & $\mathrm{Y}$ & $\mathrm{Y}$ & $\mathrm{Y}$ & $\mathrm{Y}$ & $\mathrm{Y}$ & $\mathrm{Y}$ & $\mathrm{Y}$ & $\mathrm{Y}$ & $\mathrm{Y}$ & $\mathrm{Y}$ \\
\hline Village dummies & $\mathrm{Y}$ & $\mathrm{Y}$ & $\mathrm{Y}$ & $\mathrm{Y}$ & $\mathrm{Y}$ & $\mathrm{Y}$ & $\mathrm{Y}$ & $\mathrm{Y}$ & $\mathrm{Y}$ & $\mathrm{Y}$ \\
\hline$N$ & 1099 & 1099 & 1099 & 1099 & 1099 & 1099 & 1099 & 1099 & 1099 & 1099 \\
\hline$R^{2}$ & 0.09 & 0.09 & 0.07 & 0.11 & 0.13 & 0.14 & 0.09 & 0.06 & 0.11 & 0.11 \\
\hline $\begin{array}{l}\text { Mean for control } \\
\quad \text { (Endline) }\end{array}$ & 0.20 & 0.55 & 0.04 & 0.12 & 6.16 & 3.97 & 19.13 & 10.13 & 39.38 & 78.36 \\
\hline
\end{tabular}

Data source: Authors' survey.

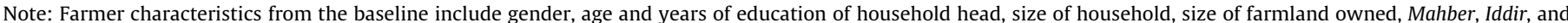

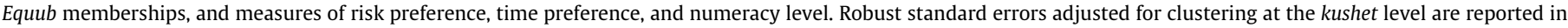
parentheses. ${ }^{* * *},{ }^{* *}$, and ${ }^{*}$ indicate significance at the 1,5 and 10 percent levels.

the intervention increased sharecropping on others' land statistically significantly by 0.17 timad. Total amount of farmland cultivated also increased by 0.26 timad, close to that of the first intervention. In the second year, however, insurance adoption did not bring positive effects on farming scale.

Interestingly, we find some evidence that farmers receiving either of our interventions reduced their own farming effort. In the first year, farmers in the input voucher group spent 1.34 fewer days on land preparation and 0.81 fewer days on sowing. These farmers, however, spent more on hiring local casual labor, an increase of 79.47 birr, suggesting that receiving intervention packages at the beginning of the agricultural season relaxed their cash constraint. As daily wages in the region were about $30 \mathrm{birr}$, on average these farmers hired nearly three more days of casual labor, doubling the baseline amount. Farmers in the input and insurance group also reduced their labor days for sowing by 0.73 days. In contrast, these farmers did not hire more casual labor, so the total level of farming effort could have been somewhat reduced.

Our IV estimates of the two-year effects tell a similar story. There is evidence that farmers receiving vouchers in the second year reduced own labor in sowing and cultivation. Those who received vouchers in both years increased their wage bills by 204 birr (i.e., almost seven days of casual labor). Altogether, these results show that relaxing cash and credit constraint through providing input subsidies produced a local spillover effect in the community by supporting substitutions of own labor by casual labor.

\subsubsection{Effects on the value of farm output and household finance}

Despite these observed changes in inputs, land, and labor, neither of the interventions is found to increase the total value of farm output (Table 6). Effect estimate of the pure input intervention, 474 birr, is greater than the value of the voucher in the first year (Column 1). However, the estimation is imprecise. The results on the insurance-voucher bundle in the first year, as well as the cumulative effect estimates over the two years, were all statistically insignificant. Nevertheless, our results are in line with related studies, such as Karlan et al. (2014), Ahmed et al. (2017), and Tobacman et al. (2017), all of which report no consistent and statistically significant effects on output values or profits.

Finally, we analyze the effects of the two programs on household financial conditions. We find that subsidizing inputs in the first year, which has been shown to stimulate different agricultural activities also increased agricultural productive assets. In contrast, the insurance-voucher bundle produced no statistically significant effects in general. We only find that farmers receiving the bundle received less private transfers from their network. However, this is also true for the farmers receiving the first intervention and we believe that the spreading of the news of receiving our interventions in the communities could be a cause. 
Table 6

Effects of input voucher and rainfall insurance on household finance.

\begin{tabular}{|c|c|c|c|c|c|c|c|c|c|c|}
\hline & $\begin{array}{l}\text { Total value of } \\
\text { farm output } \\
\text { (1) }\end{array}$ & $\begin{array}{l}\text { Off-farm } \\
\text { labor } \\
\text { income } \\
(2)\end{array}$ & $\begin{array}{l}\text { Business } \\
\text { income } \\
\text { (3) }\end{array}$ & $\begin{array}{l}\text { Health } \\
\text { expenses } \\
\text { (4) }\end{array}$ & $\begin{array}{l}\text { Education } \\
\text { expenses } \\
\text { (5) }\end{array}$ & $\begin{array}{l}\text { Productive } \\
\text { assets } \\
\text { (6) }\end{array}$ & $\begin{array}{l}\text { Livestock } \\
\text { value } \\
\text { (7) }\end{array}$ & $\begin{array}{l}\text { Cash } \\
\text { savings } \\
(8)\end{array}$ & $\begin{array}{l}\text { Private } \\
\text { transfer } \\
\text { in } \\
(9)\end{array}$ & $\begin{array}{l}\text { Private } \\
\text { transfer } \\
\text { out } \\
(10)\end{array}$ \\
\hline PANEL A (ITT-Fixed effects) & & & & & \multicolumn{6}{|c|}{ Midline - Baseline } \\
\hline Input Voucher in Year 1 & $\begin{array}{l}474.26 \\
(405.12)\end{array}$ & $\begin{array}{l}-136.45 \\
(84.59)\end{array}$ & $\begin{array}{l}-19.68 \\
(175.30)\end{array}$ & $\begin{array}{l}71.41 \\
(48.48)\end{array}$ & $\begin{array}{l}8.63 \\
(21.80)\end{array}$ & $\begin{array}{l}76.85^{*} \\
(44.60)\end{array}$ & $\begin{array}{l}353.75 \\
(435.33)\end{array}$ & $\begin{array}{l}201.93 \\
(197.77)\end{array}$ & $\begin{array}{l}-343.80^{* *} \\
(168.32)\end{array}$ & $\begin{array}{l}-27.58 \\
(51.03)\end{array}$ \\
\hline Input and Insurance in Year 1 & $\begin{array}{l}-196.18 \\
(312.35)\end{array}$ & $\begin{array}{l}124.30 \\
(84.29)\end{array}$ & $\begin{array}{l}-169.13 \\
(177.19)\end{array}$ & $\begin{array}{l}-48.19 \\
(41.04)\end{array}$ & $\begin{array}{c}-15.34 \\
(20.46)\end{array}$ & $\begin{array}{l}2.31 \\
(43.64)\end{array}$ & $\begin{array}{l}7.65 \\
(439.08)\end{array}$ & $\begin{array}{l}48.36 \\
(164.19)\end{array}$ & $\begin{array}{l}-414.79^{* *} \\
(166.70)\end{array}$ & $\begin{array}{l}-82.51 \\
(60.15)\end{array}$ \\
\hline Farmer characteristics & $\mathrm{Y}$ & $\mathrm{Y}$ & $\mathrm{Y}$ & $\mathrm{Y}$ & $\mathrm{Y}$ & $\mathrm{Y}$ & $\mathrm{Y}$ & $\mathrm{Y}$ & $\mathrm{Y}$ & $\mathrm{Y}$ \\
\hline Village dummies & $\mathrm{Y}$ & Y & $\mathrm{Y}$ & $\mathrm{Y}$ & $\mathrm{Y}$ & Y & Y & $\mathrm{Y}$ & $\mathrm{Y}$ & $\mathrm{Y}$ \\
\hline$N$ & 1149 & 1149 & 1149 & 1149 & 1149 & 1149 & 1149 & 1149 & 1149 & 1149 \\
\hline$R^{2}$ & 0.19 & 0.06 & 0.04 & 0.06 & 0.08 & 0.07 & 0.12 & 0.04 & 0.04 & 0.06 \\
\hline Mean for control (Midline) & 3858.34 & 572.22 & 451.63 & 162.03 & 306.27 & 540.51 & 7801.93 & 441.69 & 702.76 & 115.09 \\
\hline Difference in effect estimates & $\begin{array}{l}670.43^{*} \\
(379.21)\end{array}$ & $\begin{array}{l}-260.74^{* * *} \\
(88.43)\end{array}$ & $\begin{array}{l}149.45 \\
(157.28)\end{array}$ & $\begin{array}{l}119.59^{* * *} \\
(40.93)\end{array}$ & $\begin{array}{l}23.97 \\
(20.10)\end{array}$ & $\begin{array}{l}74.54 \\
(46.55)\end{array}$ & $\begin{array}{l}346.10 \\
(423.47)\end{array}$ & $\begin{array}{l}165.57 \\
(198.50)\end{array}$ & $\begin{array}{l}70.99 \\
(116.19)\end{array}$ & $\begin{array}{l}54.93 \\
(57.46)\end{array}$ \\
\hline PANEL B (IV-2SLS) & & & & & \multicolumn{6}{|c|}{ Endline - Baseline } \\
\hline $\begin{array}{l}\text { Input Voucher in Year } \\
\quad 2 \times \text { Input Voucher in Year } 1\end{array}$ & $\begin{array}{l}-170.20 \\
(360.98)\end{array}$ & $\begin{array}{l}-58.14 \\
(142.59)\end{array}$ & $\begin{array}{l}-249.06 \\
(208.42)\end{array}$ & $\begin{array}{l}27.92 \\
(36.84)\end{array}$ & $\begin{array}{l}-17.57 \\
(34.89)\end{array}$ & $\begin{array}{l}-150.88^{* *} \\
(71.09)\end{array}$ & $\begin{array}{l}-691.30 \\
(615.62)\end{array}$ & $\begin{array}{l}-238.02 \\
(213.89)\end{array}$ & $\begin{array}{l}-10.49 \\
(149.24)\end{array}$ & $\begin{array}{l}-61.18 \\
(64.91)\end{array}$ \\
\hline $\begin{array}{l}\text { Input Voucher in Year } \\
2 \times \text { Input and Insurance in } \\
\text { Year } 1\end{array}$ & $\begin{array}{l}-134.45 \\
(408.41)\end{array}$ & $\begin{array}{l}-58.72 \\
(118.39)\end{array}$ & $\begin{array}{l}-385.22 \\
(238.84)\end{array}$ & $\begin{array}{l}-27.87 \\
(47.00)\end{array}$ & $\begin{array}{l}-19.65 \\
(29.39)\end{array}$ & $\begin{array}{l}58.08 \\
(53.38)\end{array}$ & $\begin{array}{l}-425.57 \\
(594.13)\end{array}$ & $\begin{array}{l}-195.60 \\
(227.64)\end{array}$ & $\begin{array}{l}58.16 \\
(157.99)\end{array}$ & $\begin{array}{l}-56.38 \\
(61.66)\end{array}$ \\
\hline $\begin{array}{l}\text { Insurance in Year } 2 \times \text { Input } \\
\text { Voucher in Year } 1\end{array}$ & $\begin{array}{l}614.89 \\
(868.45)\end{array}$ & $\begin{array}{l}-125.12 \\
(162.78)\end{array}$ & $\begin{array}{l}-31.62 \\
(190.66)\end{array}$ & $\begin{array}{l}70.32 \\
(70.46)\end{array}$ & $\begin{array}{l}18.23 \\
(40.38)\end{array}$ & $\begin{array}{l}186.22^{* *} \\
(75.18)\end{array}$ & $\begin{array}{l}-269.49 \\
(628.85)\end{array}$ & $\begin{array}{l}-545.18^{* *} \\
(263.35)\end{array}$ & $\begin{array}{l}-143.20 \\
(227.10)\end{array}$ & $\begin{array}{l}39.47 \\
(57.97)\end{array}$ \\
\hline $\begin{array}{c}\text { Insurance in Year } 2 \times \text { Input } \\
\text { and Insurance in Year } 1\end{array}$ & $\begin{array}{l}-224.59 \\
(352.12)\end{array}$ & $\begin{array}{l}209.54 \\
(156.29)\end{array}$ & $\begin{array}{l}297.87 \\
(255.42)\end{array}$ & $\begin{array}{l}79.72 \\
(58.39)\end{array}$ & $\begin{array}{l}-8.06 \\
(25.56)\end{array}$ & $\begin{array}{l}-36.61 \\
(65.03)\end{array}$ & $\begin{array}{l}107.37 \\
(516.44)\end{array}$ & $\begin{array}{l}-243.96 \\
(179.05)\end{array}$ & $\begin{array}{l}-202.75 \\
(163.02)\end{array}$ & $\begin{array}{l}-219.47^{* * * *} \\
(81.96)\end{array}$ \\
\hline Farmer characteristics & $\mathrm{Y}$ & $\mathrm{Y}$ & $\mathrm{Y}$ & $\mathrm{Y}$ & $\mathrm{Y}$ & $\mathrm{Y}$ & $\mathrm{Y}$ & $\mathrm{Y}$ & $\mathrm{Y}$ & $\mathrm{Y}$ \\
\hline Village dummies & $\mathrm{Y}$ & $\mathrm{Y}$ & $\mathrm{Y}$ & $\mathrm{Y}$ & $\mathrm{Y}$ & $\mathrm{Y}$ & $\mathrm{Y}$ & $\mathrm{Y}$ & $\mathrm{Y}$ & $\mathrm{Y}$ \\
\hline$N$ & 1099 & 1099 & 1099 & 1099 & 1099 & 1099 & 1099 & 1099 & 1099 & 1099 \\
\hline$R^{2}$ & 0.10 & 0.06 & 0.05 & 0.04 & 0.06 & 0.08 & 0.12 & 0.05 & 0.03 & 0.06 \\
\hline Mean for control (Endline) & 2790.34 & 822.59 & 765.21 & 103.06 & 314.35 & 601.72 & 9284.10 & 905.02 & 493.78 & 147.12 \\
\hline
\end{tabular}

Data source: Authors' survey.

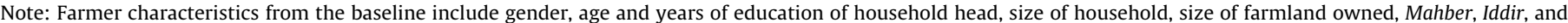

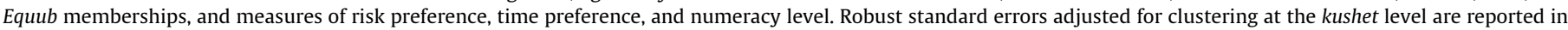
parentheses. $^{* *},{ }^{* *}$, and ${ }^{*}$ indicate significance at the 1,5 and 10 percent levels.

\section{Effect heterogeneity analysis}

We last examine effect heterogeneities of the first-year interventions on total agricultural costs (Table 7). ${ }^{22}$ We find that characteristics such as farmers' gender, age, years of education, and size of household do not interact with the two interventions in producing differential effects. Importantly, risk aversion also does not contribute to statistical differences. While this finding raises the question of whether the value of insurance is fundamentally driven by risk aversion, our sample farmers enrolled in PSNP which may have mitigated the effect of risk aversion on investments.

Interestingly, we find statistically significant results of effect heterogeneities on time preference. In the analysis, we classified farmers into two groups-more patient and less patient-using farmers' responses in a standard hypothetical game of time preference. The more patient farmers, after receiving the insurancevoucher bundle, actually raised their total agricultural costs by 350 birr, suggesting that rainfall insurance may enable them to increase investments for higher expected gains in the future. The estimate on the less patient farmers is negative (-196 birr) and statistically insignificant. Our findings illustrate a fundamental aspect of how poor farmers, when given an opportunity to insure against rainfall risks, strategically evaluate intertemporal tradeoffs. According to our results, insurance programs should be carefully marketed to encourage adoption

\footnotetext{
22 Our research is not specifically set up to detect heterogeneous effects of our interventions. Therefore, it is possible that results in this section are not statistically significant due to insufficient statistical power.
}

among farmers who are more patient and are eager to invest for the future.

Finally, we find that baseline wealth measures, such as ownership of livestock and of productive assets, did not interact with the two interventions. Farmers who had lower farming intensity in the baseline, measured by either the amount of farmland or the number of farm labor days, benefit greatly from the input voucher intervention in increasing investments. Those who had more farmland in the baseline, however, did not step up their investments, suggesting that they simply wanted more liquidity instead. Our results demonstrate the efficiency of subsidizing inputs among farmers who have a small farming scale, which is important for governments and donor agencies to consider. ${ }^{23}$

\section{Conclusion and discussion}

Our study provides experimental evidence on whether and how farmers enrolled in a government protection program would benefit from interventions aimed at further easing credit and risk constraints on agricultural production. We conducted an RCT with over 1100 farmers from 32 drought-prone villages in northern Ethiopia. Over the two years of our study, we provided PSNP farmers with different packages of input vouchers and rainfall insurance.

\footnotetext{
${ }^{23}$ We have also conducted heterogeneity analysis using the total value of farm output as the outcome variable. However, like the results on average treatment effects reported above, we generally do not find statistically significant estimates of heterogeneous treatment effects. Therefore, we do not report the results for the sake of brevity.
} 
Overall, our study has two important findings. First, our results show that the average effects of pure input voucher intervention outpaced those of a program that bundles rainfall insurance and input voucher at a similar cost. Therefore, subsidizing inputs is worthier of being adopted as an immediate measure than alleviating ex ante risk constraints for promoting agriculture. Importantly, unlike some previous studies, which report limited effects of general cash transfers on agricultural activities (e.g., Karlan et al., 2014), our input voucher intervention produced large, positive effects on both the purchase and use of seeds and fertilizers. Total agricultural costs thus increased by about $50 \%$ of the voucher value, suggesting a considerable flypaper effect on farming investments (Fafchamps et al., 2014), and the effect was larger among farmers who had a lower level of farming scale at the baseline. The input voucher intervention also produced complementary effects on increasing farming scale (Chibwana, Fisher, \& Shively, 2012). Importantly, farmers who received input vouchers reduced their own effort and paid extra wages to hire more casual labor, and these spillover benefits of relaxing cash and credit constraint in local networks could represent a substitution in the labor arrangement due to wealth and relative price effects (Angelucci \& de Giorgi, 2009).

Second, we also document the difficulties in the financing, promotion, and adoption of insurance for many poor farmers enrolled in government protection programs. Our insurancevoucher program at best produced weak effects on stimulating agricultural activities in the immediate term, suggesting that farmers may not be able to experience and take advantage of the potential benefits of insurance protection during normal seasons. Ethiopian PSNP farmers are also highly sensitive to price and experiencing free insurance cannot greatly increase future insurance adoption. Therefore, subsidizing insurance is unlikely a financially sustainable way to promote adoption and enable formal ex ante risk management. Nevertheless, our insurancevoucher bundle is found to raise total agricultural spending among farmers who were more patient. In other words, insurance was able to support patient farmers to undertake investments for potentially higher returns in future (Duflo et al., 2011). However, as these patient farmers did not exhibit higher insurance demand, sophisticated marketing strategy and targeting approaches, which may include subject-specific activities and related tools, should be integrated into the design and implementation of insurance programs to help these farmers obtain the insurance and maximize program benefits.

\section{Declaration of Competing Interest}

The authors declare that they have no known competing financial interests or personal relationships that could have appeared to influence the work reported in this paper.

\section{Acknowledgements}

This project is part of the research agenda of the Knowledge Platform Inclusive Development Policies and funded by the Ministry of Foreign Affairs of the Netherlands through NWO-WOTRO (W 08.390.002). We also acknowledge research funding support from Lingnan University Direct Grant. These funding bodies do not involve in the research or the writing of the project. We declare no competing interest. We thank our fieldwork supervisors and enumerators for spending weeks in the rural part of Northern Ethiopia to collect data and carry out experimental interventions, and all our helpers for cleaning and compiling the data. 
Table A1

Understanding of rainfall insurance after village training and participatory exercises.

\begin{tabular}{|c|c|c|c|c|c|c|}
\hline & \multicolumn{6}{|c|}{ Percentage of correct responses (\%) } \\
\hline & $\begin{array}{l}\text { Year } 1 \text { responses: } \\
\text { Farmers in Input and } \\
\text { Insurance Group only } \\
\text { (1) }\end{array}$ & $\begin{array}{l}\text { Year } 2 \\
\text { responses: All } \\
\text { treated } \\
\text { farmers } \\
(2)\end{array}$ & $\begin{array}{l}\text { Year } 2 \text { responses: Farmers } \\
\text { in Input and Insurance } \\
\text { Group in Year } 1 \\
\text { (3) }\end{array}$ & $\begin{array}{l}\text { Year } 2 \text { responses: } \\
\text { Farmers in Input } \\
\text { Voucher Group in Year } \\
1 \\
(4)\end{array}$ & $\begin{array}{l}\text { Year } 2 \text { responses: } \\
\text { Farmers took up } \\
\text { insurance in Year } 2 \\
\text { (5) }\end{array}$ & $\begin{array}{l}\text { Year } 2 \text { responses: } \\
\text { Farmers did not take up } \\
\text { insurance in Year } 2 \\
\text { (6) }\end{array}$ \\
\hline $\begin{array}{l}\text { Q1: Before providing you the insurance, do we need to visit your farm? } \\
\text { A1: No }\end{array}$ & 84.8 & 88.3 & 88.6 & 88.0 & 87.5 & 89.2 \\
\hline $\begin{array}{l}\text { Q2: Before determining the amount of insurance payout, do we need to } \\
\text { visit your farm to evaluate if you suffer from crop loss? } \\
\text { A2: No }\end{array}$ & 94.2 & 87.5 & 87.5 & 87.4 & 88.0 & 86.8 \\
\hline $\begin{array}{l}\text { Q3: When will the insurance give you a payout? } \\
\text { A3: When rainfall in the village is below a certain level according to } \\
\text { satellite }\end{array}$ & 93.3 & 70.0 & 68.8 & 71.2 & 70.8 & 68.9 \\
\hline $\begin{array}{l}\text { Q4: If you will receive an insurance payout, will the payout depend on the } \\
\text { amount of agricultural inputs that you make on your farm? } \\
\text { A4: No }\end{array}$ & 93.6 & 69.2 & 68.8 & 69.6 & 66.2 & 72.9 \\
\hline $\begin{array}{l}\text { Q5: Can you tell us how we will measure the amount of rainfall? } \\
\text { A5: Satellite in the sky }\end{array}$ & 95.5 & 94.1 & 95.4 & 92.9 & 94.4 & 93.9 \\
\hline $\begin{array}{l}\text { Q6: If your crop is damaged by pests, will you receive payout from the } \\
\text { insurance? } \\
\text { A6: No }\end{array}$ & 91.2 & 93.5 & 94.3 & 92.6 & 92.9 & 94.2 \\
\hline $\begin{array}{l}\text { Q7: If you will receive an insurance payout, will the payout cover all your } \\
\text { crop loss? }\end{array}$ & 89.9 & 86.6 & 87.5 & 85.8 & 87.8 & 85.2 \\
\hline $\begin{array}{l}\text { A7: No } \\
\text { Q8: If you are insured for wheat for a harvest value of } 2000 \text { birr and you } \\
\text { suffer from a loss of } 5000 \text { birr, what is the maximum amount of } \\
\text { payout you can receive in the worst drought? }\end{array}$ & 84.6 & 82.1 & 84.2 & 80.0 & 85.8 & 77.5 \\
\hline $\begin{array}{l}\text { A8: } 2000 \text { birr } \\
\text { Q9: Is this true that rainfall index insurance guarantees you a payout } \\
\text { every three to five years? }\end{array}$ & 77.4 & 80.5 & 80.7 & 80.2 & 82.8 & 77.5 \\
\hline A9: No & & & & & & \\
\hline Overall percentage & 89.4 & 83.5 & 84.0 & 83.1 & 84.0 & 82.9 \\
\hline Number of observations & 376 & 733 & 368 & 365 & 408 & 325 \\
\hline
\end{tabular}

Data source: Authors' survey. 
Table A3

Insurance participation by first-year intervention status and second-year subsidized insurance cost among PSNP farmers in the second-year experiment.

\begin{tabular}{|c|c|c|}
\hline & \multicolumn{2}{|c|}{$\begin{array}{l}\text { Farmer } \\
\text { participated in } \\
\text { rainfall } \\
\text { insurance in } \\
\text { Year } 2 \text { ( } 1 \text { = Yes; } \\
0=\text { No) }\end{array}$} \\
\hline $\begin{array}{l}\text { Treated in Year } 1 \times 90 \% \text { Insurance Subsidy in Year } 2 \\
\quad(1=\text { Yes; } 0=\text { No })\end{array}$ & $\begin{array}{l}0.87^{* * *} \\
(0.04)\end{array}$ & \\
\hline $\begin{array}{l}\text { Treated in Year } 1 \times 80 \% \text { Insurance Subsidy in Year } 2 \\
\quad(1=\text { Yes; } 0=\text { No })\end{array}$ & $\begin{array}{l}0.74^{* * *} \\
(0.04)\end{array}$ & \\
\hline $\begin{array}{l}\text { Treated in Year } 1 \times 70 \% \text { Insurance Subsidy in Year } 2 \\
\quad(1=\text { Yes; } 0=\text { No })\end{array}$ & $\begin{array}{l}0.64^{* * *} \\
(0.05)\end{array}$ & \\
\hline $\begin{array}{l}\text { Treated in Year } 1 \times 60 \% \text { Insurance Subsidy in Year } 2 \\
\quad(1=\text { Yes; } 0=\text { No })\end{array}$ & $\begin{array}{l}0.44^{* * *} \\
(0.04)\end{array}$ & \\
\hline $\begin{array}{l}\text { Treated in Year } 1 \times 50 \% \text { Insurance Subsidy in Year } 2 \\
\quad(1=\text { Yes; } 0=\text { No })\end{array}$ & $\begin{array}{l}0.38^{* * *} \\
(0.05)\end{array}$ & \\
\hline $\begin{array}{l}\text { Treated in Year } 1 \times 40 \% \text { Insurance Subsidy in Year } 2 \\
\quad(1=\text { Yes; } 0=\text { No })\end{array}$ & $\begin{array}{l}0.15^{* * *} \\
(0.03)\end{array}$ & \\
\hline $\begin{array}{l}\text { Input Voucher in Year } 1 \times 90 \% \text { Insurance Subsidy in Year } 2 \\
\quad(1=\text { Yes; } 0=\text { No })\end{array}$ & & $\begin{array}{l}0.83^{* * *} \\
(0.05)\end{array}$ \\
\hline $\begin{array}{l}\text { Input Voucher in Year } 1 \times 80 \% \text { Insurance Subsidy in Year } 2 \\
\quad(1=\text { Yes; } 0=\text { No })\end{array}$ & & $\begin{array}{l}0.70^{* * *} \\
(0.06)\end{array}$ \\
\hline $\begin{array}{l}\text { Input Voucher in Year } 1 \times 70 \% \text { Insurance Subsidy in Year } 2 \\
\quad(1=\text { Yes; } 0=\text { No })\end{array}$ & & $\begin{array}{l}0.58^{* * *} \\
(0.06)\end{array}$ \\
\hline $\begin{array}{l}\text { Input Voucher in Year } 1 \times 60 \% \text { Insurance Subsidy in Year } 2 \\
\quad(1=\text { Yes; } 0=\text { No })\end{array}$ & & $\begin{array}{l}0.42^{* * * *} \\
(0.06)\end{array}$ \\
\hline $\begin{array}{l}\text { Input Voucher in Year } 1 \times 50 \% \text { Insurance Subsidy in Year } 2 \\
\quad(1=\text { Yes; } 0=\text { No })\end{array}$ & & $\begin{array}{l}0.35^{* * *} \\
(0.06)\end{array}$ \\
\hline $\begin{array}{l}\text { Input Voucher in Year } 1 \times 40 \% \text { Insurance Subsidy in Year } 2 \\
\quad(1=\text { Yes; } 0=\text { No })\end{array}$ & & $\begin{array}{l}0.14^{* * *} \\
(0.05)\end{array}$ \\
\hline $\begin{array}{l}\text { Input and Insurance in Year } 1 \times 90 \% \text { Insurance Subsidy in } \\
\text { Year } 2 \\
(1=\text { Yes; } 0=\text { No })\end{array}$ & & $\begin{array}{l}0.90^{* * *} \\
(0.05)\end{array}$ \\
\hline $\begin{array}{l}\text { Input and Insurance in Year } 1 \times 80 \% \text { Insurance Subsidy in } \\
\text { Year } 2 \\
(1=\text { Yes; } 0=\text { No })\end{array}$ & & $\begin{array}{l}0.78^{* * *} \\
(0.05)\end{array}$ \\
\hline $\begin{array}{l}\text { Input and Insurance in Year } 1 \times 70 \% \text { Insurance Subsidy in } \\
\text { Year } 2 \\
(1=\text { Yes; } 0=\text { No })\end{array}$ & & $\begin{array}{l}0.71^{* * *} \\
(0.06)\end{array}$ \\
\hline $\begin{array}{l}\text { Input and Insurance in Year } 1 \times 60 \% \text { Insurance Subsidy in } \\
\text { Year } 2 \\
(1=\text { Yes; } 0=\text { No })\end{array}$ & & $\begin{array}{l}0.46^{* * *} \\
(0.06)\end{array}$ \\
\hline $\begin{array}{l}\text { Input and Insurance in Year } 1 \times 50 \% \text { Insurance Subsidy in } \\
\text { Year } 2 \\
(1=\text { Yes; } 0=\text { No })\end{array}$ & & $\begin{array}{l}0.42^{* * *} \\
(0.06)\end{array}$ \\
\hline $\begin{array}{l}\text { Input and Insurance in Year } 1 \times 40 \% \text { Insurance Subsidy in } \\
\text { Year } 2 \\
(1=\text { Yes; } 0=\text { No })\end{array}$ & & $\begin{array}{l}0.17^{* * *} \\
(0.04)\end{array}$ \\
\hline Farmer characteristics & $\mathrm{Y}$ & $\mathrm{Y}$ \\
\hline Village dummies & $\mathrm{Y}$ & $\mathrm{Y}$ \\
\hline Observations & 1099 & 1099 \\
\hline$R^{2}$ & 0.52 & 0.53 \\
\hline
\end{tabular}

Data source: Authors' survey.

Note: Farmer characteristics from the baseline include gender, age and years of education of household head, size of household, size of farmland, Mahber, Iddir, and Equub memberships, and measures of risk preference, time preference, and numeracy level. Robust standard errors adjusted for clustering at the kushet level are reported in parentheses. ${ }^{* * *},{ }^{* *}$, and ${ }^{*}$ indicate significance at the 1,5 and 10 percent levels.
Table A2

Attrition analysis of sample farmers.

\begin{tabular}{|c|c|c|}
\hline & $\begin{array}{l}\text { Farmer } \mathrm{r} \\
\text { the endli } \\
(1=\text { Yes; } \\
(1)\end{array}$ & $\begin{array}{l}\text { hissing in } \\
\text { ne survey } \\
0=\text { No) } \\
(2)\end{array}$ \\
\hline $\begin{array}{l}\text { Treated in Year } 1 \times 90 \% \text { Insurance Subsidy in Year } 2 \\
\quad(1=\text { Yes; } 0=\text { No })\end{array}$ & $\begin{array}{l}-0.02 \\
(0.02)\end{array}$ & \\
\hline $\begin{array}{l}\text { Treated in Year } 1 \times 80 \% \text { Insurance Subsidy in Year } 2 \\
\quad(1=\text { Yes; } 0=\mathrm{No})\end{array}$ & $\begin{array}{l}-0.01 \\
(0.02)\end{array}$ & \\
\hline $\begin{array}{l}\text { Treated in Year } 1 \times 70 \% \text { Insurance Subsidy in Year } 2 \\
\quad(1=\text { Yes; } 0=\text { No })\end{array}$ & $\begin{array}{l}-0.03 \\
(0.02)\end{array}$ & \\
\hline $\begin{array}{l}\text { Treated in Year } 1 \times 60 \% \text { Insurance Subsidy in Year } 2 \\
\quad(1=\text { Yes; } 0=\text { No })\end{array}$ & $\begin{array}{l}-0.02 \\
(0.02)\end{array}$ & \\
\hline $\begin{array}{l}\text { Treated in Year } 1 \times 50 \% \text { Insurance Subsidy in Year } 2 \\
\quad(1=\text { Yes; } 0=\text { No })\end{array}$ & $\begin{array}{l}-0.05^{* * *} \\
(0.01)\end{array}$ & \\
\hline $\begin{array}{l}\text { Treated in Year } 1 \times 40 \% \text { Insurance Subsidy in Year } 2 \\
\quad(1=\text { Yes; } 0=\text { No })\end{array}$ & $\begin{array}{l}-0.01 \\
(0.02)\end{array}$ & \\
\hline $\begin{array}{l}\text { Input Voucher in Year } 1 \times 90 \% \text { Insurance Subsidy in Year } \\
2 \\
\quad(1=\text { Yes; } 0=\text { No })\end{array}$ & & $\begin{array}{l}0.00 \\
(0.03)\end{array}$ \\
\hline $\begin{array}{l}\text { Input Voucher in Year } 1 \times 80 \% \text { Insurance Subsidy in Year } \\
2 \\
\quad(1=\text { Yes; } 0=\text { No })\end{array}$ & & $\begin{array}{l}-0.03 \\
(0.02)\end{array}$ \\
\hline $\begin{array}{l}\text { Input Voucher in Year } 1 \times 70 \% \text { Insurance Subsidy in Year } \\
2 \\
(1=\text { Yes; } 0=\text { No })\end{array}$ & & $\begin{array}{l}-0.02 \\
(0.03)\end{array}$ \\
\hline $\begin{array}{l}\text { Input Voucher in Year } 1 \times 60 \% \text { Insurance Subsidy in Year } \\
2 \\
\quad(1=\text { Yes; } 0=\text { No })\end{array}$ & & $\begin{array}{l}0.03 \\
(0.04)\end{array}$ \\
\hline $\begin{array}{l}\text { Input Voucher in Year } 1 \times 50 \% \text { Insurance Subsidy in Year } \\
2 \\
(1=\text { Yes; } 0=\text { No })\end{array}$ & & $\begin{array}{l}-0.05^{* * *} \\
(0.01)\end{array}$ \\
\hline $\begin{array}{l}\text { Input Voucher in Year } 1 \times 40 \% \text { Insurance Subsidy in Year } \\
2 \\
(1=\text { Yes; } 0=\text { No })\end{array}$ & & $\begin{array}{l}-0.02 \\
(0.02)\end{array}$ \\
\hline $\begin{array}{l}\text { Input and Insurance in Year } 1 \times 90 \% \text { Insurance Subsidy } \\
\text { in Year } 2 \\
(1=\text { Yes; } 0=\text { No })\end{array}$ & & $\begin{array}{l}-0.04^{* *} \\
(0.02)\end{array}$ \\
\hline $\begin{array}{l}\text { Input and Insurance in Year } 1 \times 80 \% \text { Insurance Subsidy } \\
\text { in Year } 2 \\
(1=\text { Yes; } 0=\text { No })\end{array}$ & & $\begin{array}{l}0.00 \\
(0.03)\end{array}$ \\
\hline $\begin{array}{l}\text { Input and Insurance in Year } 1 \times 70 \% \text { Insurance Subsidy } \\
\text { in Year } 2 \\
(1=\text { Yes; } 0=\text { No })\end{array}$ & & $\begin{array}{l}-0.04 \\
(0.03)\end{array}$ \\
\hline $\begin{array}{l}\text { Input and Insurance in Year } 1 \times 60 \% \text { Insurance Subsidy } \\
\text { in Year } 2 \\
(1=\text { Yes; } 0=\text { No })\end{array}$ & & $\begin{array}{l}-0.06^{* * *} \\
(0.02)\end{array}$ \\
\hline $\begin{array}{l}\text { Input and Insurance in Year } 1 \times 50 \% \text { Insurance Subsidy } \\
\text { in Year } 2 \\
(1=\text { Yes; } 0=\text { No })\end{array}$ & & $\begin{array}{l}-0.06^{* * * *} \\
(0.02)\end{array}$ \\
\hline $\begin{array}{l}\text { Input and Insurance in Year } 1 \times 40 \% \text { Insurance Subsidy } \\
\text { in Year } 2 \\
(1=\text { Yes; } 0=\text { No })\end{array}$ & & $\begin{array}{l}0.01 \\
(0.03)\end{array}$ \\
\hline Farmer characteristics & $\mathrm{Y}$ & $\mathrm{Y}$ \\
\hline Village dummies & $\mathrm{Y}$ & $\mathrm{Y}$ \\
\hline Observations & 1149 & 1149 \\
\hline$R^{2}$ & 0.06 & 0.07 \\
\hline
\end{tabular}

Data source: Authors' survey.

Note: Farmer characteristics from the baseline include gender, age and years of education of household head, size of household, Mahber, Iddir, and Equub memberships, and measures of risk preference, time preference, and numeracy level. Robust standard errors adjusted for clustering at the kushet level are reported in parentheses. ${ }^{* * *},{ }^{* *}$ and ${ }^{*}$ indicate statistical significance at 1,5 and 10 percent levels. 


\section{Appendix A. Supplementary data}

Supplementary data to this article can be found online at https://doi.org/10.1016/j.worlddev.2020.105074.

\section{References}

Ahmed, S., McIntosh, C., \& Sarris, A. (2017). The impact of commercial rainfall index insurance: Experimental evidence from Ethiopia. Working paper.

Alderman, H., \& Haque, T. (2007). Insurance against covariate shocks: The role of index-based insurance in social protection in low-income countries of Africa. World Bank Working Paper No. 95.

Andersson, C., Mekonnen, A., \& Stage, J. (2011). Impacts of the productive safety net program in Ethiopia on livestock and tree holdings of rural households. Journal of Development Economics, 94(1), 119-126.

Angelucci, M., \& de Giorgi, G. (2009). Indirect effects of an aid program: How do cash transfers affect ineligibles' consumption?. American Economic Review, 99 (1), 486-508

Barnett, B. J., Barrett, C. B., \& Skees, J. R. (2008). Poverty traps and index-based risk transfer products. World Development, 36(10), 1766-1785.

Barnett, B. J., \& Mahul, O. (2007). Weather index insurance for agriculture and rural areas in lower-income countries. American Journal of Agricultural Economics, 89 (5), 1241-1247.

Beaman, L., Karlan, D., Thuysbaert, B., \& Udry, C. (2013). Profitability of fertilizer: Experimental evidence from female rice farmers in Mali. American Economic Review: Papers and Proceedings, 103, 381-386.

Berhane, G., Gilligan, D. O., Hoddinott, J., Kumar, N., \& Taffesse, A. S. (2014). Can social protection work in Africa? The impact of Ethiopia's productive safety net programme. Economic Development and Cultural Change, 63(1), 1-26.

Bhattamishra, R., \& Barrett, C. B. (2010). Community-based risk management arrangements: A review. World Development, 38(7), 923-932.

Bloom, H. S. (1995). Minimum detectable effects: A simple way to report the statistical power of experimental designs. Evaluation Review, 19, 547-556.

Cai, J. (2016). The impact of insurance provision on household production and financial decisions. American Economic Journal: Economic Policy, 8(2), 44-88.

Cai, J., De Janvry, A., \& Sadoulet, E. (2015). Social networks and the decision to insure. American Economic Journal: Applied Economics, 7(2), 81-108.

Carter, M. R., Cheng, L., \& Sarris, S. (2016). Where and how index insurance can boost the adoption of improved agricultural technologies. Journal of Development Economics, 118, 59-71.

Chantarat, S., Barrett, B. C., Mude, G. A., \& Turvey, G. C. (2007). Using weather index insurance to improve drought response for famine prevention. American Journal of Agricultural Economics, 89(5), 1262-1268.

Chibwana, C., Fisher, M., \& Shively, G. (2012). Cropland allocation effects of agricultural input subsidies in Malawi. World Development, 40(1), 124-133.

Churchill, C. (Ed.). (2006). Protecting the Poor: A Microinsurance Compendium. Geneva: International Labour Organization.

Clarke, D. J. (2016). A theory of rational demand for index insurance. American Economic Journal: Microeconomics, 8(1), 283-306.

Cole, S., Bastian, G., Vyas, S., Wendel, C., \& Stein, D. (2012). The effectiveness of indexbased micro-insurance in helping smallholders manage weather-related risks. London: EPPI-Centre, Social Science Research Unit, Institute of Education, University of London.

Cole, S., Giné, X., \& Vickery, J. (2017). How does risk management influence production decisions? Evidence from a field experiment. Review of Financial Studies, 30(6), 1935-1970.

Cole, S., Giné, X., Tobacman, J., Topalova, P., Townsend, R., \& Vickery, J. (2013). Barriers to household risk management: Evidence from India. American Economic Journal: Applied Economics, 5(1), 104-135.

Cole, S., Stein, D., \& Tobacman, J. (2014). Dynamics of demand for index insurance: Evidence from a long-run field experiment. American Economic Review: Papers E Proceedings, 104(5), 284-290.

de Brauw, A., \& Hoddinott, J. (2011). Must conditional cash transfer programs be conditioned to be effective? The impact of conditioning transfers on school enrollment in Mexico. Journal of Development Economics, 96, 359-370.

de Janvry, A., Dequiedt, V., \& Sadoulet, E. (2014). The demand for insurance against common shocks. Journal of Development Economics, 106, 227-238.

de Janvry, A., Finan, F., Sadoulet, E., \& Vakis, R. (2006). Can conditional cash transfer programs serve as safety nets in keeping children at school and from working when exposed to shocks? Journal of Development Economics, 79, 349-373.

Dercon, S. (2004). Growth and shocks: Evidence from Rural Ethiopia. Journal of Development Economics, 74, 309-329.

Devereux, S. (2016). Social protection for enhanced food security in sub-Saharan Africa. Food Policy, 60, 52-62.

Duflo, E., Kremer, M., \& Robinson, J. (2011). Nudging farmers to use fertilizer: Theory and experimental evidence from Kenya. American Economic Review, 101, 2350-2390.

Duru, M. J. (2016). Too certain to invest? Public safety nets and insurance markets in Ethiopia. World Development, 78, 37-51.

Fafchamps, M., McKenzie, D., Quinn, S., \& Woodruff, C. (2014). Microenterprise growth and the flypaper effect: Evidence from a randomized experiment in Ghana. Journal of Development Economics, 106, 211-226.

Filipski, M., Taylor, J.E., Abegaz, G.A., Ferede, T., Taffesse, A.S., \& Diao, X. (2017). General equilibrium impact assessment of the Productive Safety Net Program in
Ethiopia. 3ie Impact Evaluation Report 66. New Delhi: International Initiative for Impact Evaluation (3ie).

Filmer, D., \& Schady, N. (2011). Does more cash in conditional cash transfer programs always lead to larger impacts on school attendance?. Journal of Development Economics, 96, 150-157.

Gao, J., \& Mills, B. F. (2017). Weather shocks, coping strategies, and consumption dynamics in Rural Ethiopia. World Development, 101, 268-283.

Gaurav, S., Cole, S., \& Tobacman, J. (2011). Marketing complex financial products in emerging markets: Evidence from rainfall insurance in India. Journal of Marketing Research, 48, 150-162.

Gilligan, D., Hoddinott, J., \& Taffesse, A. (2009). The impact of Ethiopia's productive safety net programme and its linkages. Journal of Development Studies, 45(10), 1684-1706.

Giné, X., Townsend, R., \& Vickery, J. (2008). Patterns of rainfall insurance participation in Rural India. World Bank Economic Review, 22(3), 539-566.

Giné, X., \& Yang, D. (2009). Insurance, credit, and technology adoption: Field experimental evidence from Malawi. Journal of Development Economics, 89, 1-11.

Greatrex, H., Hansen, J., Garvin, S., Diro, R., Blakeley, S., Le Guen, M. et al. (2015). Scaling up index insurance for smallholder farmers: Recent evidence and insights. CCAFS Report No. 14. Copenhagen, Denmark: CGIAR Research Program on Climate Change, Agriculture and Food Security (CCAFS).

Hellmuth, M.E., Osgood, D.E., Hess, U., Moorhead, A., \& Bhojwani, H. (eds.). (2009) Index insurance and climate risk: Prospects for development and disaster management. Climate and Society No. 2. International Research Institute for Climate and Society (IRI), Columbia University, New York, USA.

High Level Panel of Experts (HLPE). (2012). Social protection for food security. A report by the High Level Panel of Experts (HLPE) on Food Security and Nutrition of the Committee on World Food Security (CFS). CFS, Rome.

Hill, V. R., \& Viceisza, A. (2012). A field experiment on the impact of weather shocks and insurance on risky investment. Experimental. Economics, 15(2), $341-371$.

Hoddinott, H., Berhane, G., O'Gilligan, D., Kumar, N., \& Taffesse, A. S. (2012). The impact of Ethiopia's productive safety net programme and related transfers on agricultural productivity. Journal of African Economies, 21(5), 761-786.

International Fund for Agricultural Development and World Food Programme. (2010). The potential for scale and sustainability in weather index insurance for agriculture and rural livelihoods, by P. Hazell, J. Anderson, N. Balzer, A. Hastrup Clemmensen, U. Hess, and F. Rispoli. Rome.

Jayne, T. S., Mason, N. M., Burke, W. J., \& Ariga, J. (2018). Review: Taking stock of Africa's second-generation agricultural input subsidy programs. Food Policy, 75 $1-14$.

Jensen, N. D., Barrett, C. B., \& Mude, A. G. (2017). Cash transfers and index insurance: A comparative impact analysis from Northern Kenya. Journal of Development Economics, 129, 14-28.

Jones, N., Tafere, Y., \& Woldehanna, T. (2010). Gender Risk, Poverty and Vulnerability in Ethiopia: To What Extent is the Productive Safety Net Programme (PSNP) Making a Difference?. London, UK: Overseas Development Institute.

Karlan, D., Osei, R., Osei-Akoto, I., \& Udry, C. (2014). Agricultural decisions after relaxing credit and risk constraints. Quarterly Journal of Economics, 20, 597-652.

Madejewicz, M., \& Tsegay, A. H. (2013). Managing risks to agricultural livelihoods: Impact evaluations of the HARITA program in Tigray, Ethiopia, 2009-2012. Oxfam External Evaluation Report.

Madejewicz, M., Tsegay, A. H., \& Lee, R. (2017). Managing risks in smallholder agriculture: The impacts of R4 on livelihoods. Tigray, Ethiopia from 2012 to 2016. Oxfam. External Evaluation Report.

Mahul, O., \& Stutley, C. J. (2010). Government support to agricultural insurance: Challenges and options for developing countries. World Bank.

Maluccio, J. A. (2010). The impact of conditional cash transfers on consumption and investment in Nicaragua. Journal of Development Studies, 46(1), 14-38.

Milazzo, A., \& van de Walle, D. (2017). Women Left Behind? Poverty and Headship in Africa. Demography, 54, 1119-1145.

Miller, C. M., Tsoka, M., \& Reichert, K. (2011). The impact of the social cash transfer scheme on food security in Malawi. Food Policy, 36, 230-238.

Morris, M., Kelly, V. A., Kopicki, R. J., \& Byerlee, D. (2007). Fertilizer Use in African Agriculture: Lessons Learned andGood Practice Guidelines. Washington D.C.: World Bank.

Norton, M., Osgood, D., Madajewicz, M., Holthaus, E., Peterson, N., Diro, R., .. Gebremichael, M. (2014). Evidence of demand for index insurance: Experimental games and commercial transactions in Ethiopia. Journal of Development Studies, 50(5), 630-648.

Platteau, J. P., De Bock, O., \& Gelade, W. (2017). The demand for microinsurance: A literature review. World Development, 94, 139-156.

Results UK. (2016). Weathering a risky climate: The role of insurance in reducing vulnerability to extreme weather.

Schultz, T. P. (2004). School subsidies for the poor: Evaluating the Mexican PROGRESA poverty program. Journal of Development Economics, 74(1), 199-250.

Sharp, K., Brown, T., \& Teshome, A. (2006). Targeting Ethiopia's Productive Safety Net Programme (PSNP). London and Bristol: Overseas Development Institute and The IDL Group.

Spielman, D. J., Kelemwork, D., \& Alemu, D. (2011). Seed, fertilizer, and agricultural extension in Ethiopia. International Food Policy Research Institute (IFPRI) Ethiopia Strategy Support Program (ESSP) II Working Paper No. 20.

Tobacman, J., Stein, D., Shah, V., Litvine, L., Cole, S., and Chattopadhyay, R. (2017). Insuring farmers against weather shocks: Evidence from India. 3ie Impact Evaluation Report 29. New Delhi: International Initiative for Impact Evaluation (3ie). 
Todd, J. E., Winters, P. C., \& Hertz, T. (2010). Conditional cash transfers and agricultural production: Lessons from the Oportunidades experience in Mexico. Journal of Development Studies, 46(1), 39-67.

Vasilaky, K., Diro, R., Norton, M., McCarnery, G., \& Osgood, D. (2018). Educational games in Ethiopia: Scaling the demand for index insurance. Working Paper.

World Bank (2013a). Ethiopia's Productive Safety Net Program (PSNP) Integrating Disaster and Climate Risk Management: Case Study. Washington DC: World Bank. World Bank (2013b). Ethiopia: Using a social safety net to deliver disaster insurance to the poor. World Bank Working Paper No. 80623.
World Bank. (2017). World Bank to help Ethiopia build a national safety net system as a more effective response to droughts. Retrieved online on April 20, 2018. http://www.worldbank.org/en/news/press-release/2017/09/14/world-bank-tohelp-ethiopia-build-a-national-safety-net-system-as-a-more-effectiveresponse-to-droughts.

World Food Program. (2017). 2017 - R4 Rural Resilience Initiative Factsheet. https://docs.wfp.org/api/documents/

b9a3d33bd9974e5aaf01b11a3e3da410/download/? ga=2.198547302.

$853521952.1535556979-464647912.1535556979$. 